\title{
RADIOCARBON DATES FROM JAR AND COFFIN BURIALS OF THE CARDAMOM MOUNTAINS REVEAL A UNIQUE MORTUARY RITUAL IN CAMBODIA'S LATE- TO POST-ANGKOR PERIOD (15TH-17TH CENTURIES AD)
}

\author{
Nancy Beavan ${ }^{1,2} \cdot$ Sian Halcrow $^{1} \cdot$ Bruce McFadgen $^{3} \cdot$ Derek Hamilton $^{4} \bullet$ Brendan Buckley $^{5} \bullet$ \\ Tep Sokha ${ }^{6}$ Louise Shewan ${ }^{7}$ Ouk Sokha ${ }^{8}$ - Stewart Fallon ${ }^{9} \cdot$ John Miksic $^{10} \bullet$ \\ Richard Armstrong ${ }^{9} \cdot$ Dougald O'Reilly $^{11} \bullet{\text { Kate } \text { Domett }^{12} \cdot \mathrm{K}^{\mathrm{R}} \text { Chhem }}^{13}$
}

\begin{abstract}
We present the first radiocarbon dates from previously unrecorded, secondary burials in the Cardamom Mountains, Cambodia. The mortuary ritual incorporates nautical tradeware ceramic jars and log coffins fashioned from locally harvested trees as burial containers, which were set out on exposed rock ledges at 10 sites in the eastern Cardamom Massif. The suite of $28{ }^{14} \mathrm{C}$ ages from 4 of these sites (Khnorng Sroal, Phnom Pel, Damnak Samdech, and Khnang Tathan) provides the first estimation of the overall time depth of the practice. The most reliable calendar date ranges from the 4 sites reveals a highland burial ritual unrelated to lowland Khmer culture that was practiced from cal AD 1395 to 1650 . The time period is concurrent with the 15th century decline of Angkor as the capital of the Khmer kingdom and its demise about AD 1432, and the subsequent shift of power to new Mekong trade ports such as Phnom Penh, Udong, and Lovek. We discuss the Cardamom ritual relative to known funerary rituals of the pre- to post-Angkorian periods, and to similar exposed jar and coffin burial rituals in Mainland and Island Southeast Asia.
\end{abstract}

\section{INTRODUCTION}

Archaeological and anthropological scholarship on the Khmer culture has produced a rich and varied body of work on topics such as Indian influences on Angkorian state formation and the evolution of Khmer economies from prehistory to the 15 th century AD. The span of these works are a comprehensive historical assessment of the Khmer kingdom and significant neighboring regions, from the Khmer polity's earliest beginnings to its zenith (e.g. Coedès 1968; Wolters 1974, 1979; Hagesteijn 1989, 1996; Higham and Thosarat 1998; Higham 2002; O’Reilly 2007), but these studies are mainly confined to the plains, the Mekong Delta, and foothills. Although the bulk of material culture constituting what is known about Khmer cultural history is derived predominately from research conducted in the lowlands, research on cultures contemporary with the Angkorian state in the highland regions is nonexistent.

Archaeological investigations of highland cultures pose particular challenges. Surviving physical evidence of settlement is rare or difficult to identify, as many highland cultures utilize temporary encampments due to the seasonal nature of swidden agriculture and other food-gathering strategies. Mountainous terrain also makes such investigations challenging. Our area of interest, the Cardamom Mountains (Chuor Phnom Krâvanh) in the southwest of Cambodia (Figure 1), presents just such a challenge. The $20,000 \mathrm{~km}$ of the Cardamom Massif is roughly aligned southeast to northwest,

\footnotetext{
${ }^{1}$ Department of Anatomy, University of Otago Medical School, PO Box 913, Dunedin 9054, New Zealand.

${ }^{2}$ Corresponding author. Email: nancy.beavan@anatomy.otago.ac.nz.

${ }^{3}$ School of Maori Studies, Victoria University of Wellington, Wellington, New Zealand.

${ }^{4}$ SUERC Radiocarbon Dating Laboratory, East Kilbride, Scotland.

${ }^{5}$ Tree-Ring Laboratory, Lamont Doherty Earth Observatory, Palisades, New York, USA.

${ }^{6}$ Ceramics Conservation Laboratory, Royal University of Fine Arts, Phnom Penh, Cambodia.

${ }^{7}$ Sydney Medical School, University of Sydney, Sydney, Australia.

${ }^{8}$ Ministry of Culture and Fine Arts, Phnom Penh, Kingdom of Cambodia.

${ }^{9}$ Research School of Earth Sciences, Australian National University, Canberra, Australia.

${ }^{10}$ Southeast Asian Studies Program, National University of Singapore, Singapore.

${ }^{11}$ School of Archaeology and Anthropology, Australian National University, Australia.

${ }^{12}$ James Cook University, Queensland, Australia.

${ }^{13}$ Institute of History, Philosophy and Ethics of Medicine, Ulm University, Ulm, Germany.
} 
with foothills transitioning to forested peaks of more than $1500 \mathrm{~m}$ interspersed by wide basins and narrow valleys. The rugged terrain and isolation of the region has given it notoriety over the centuries as a place of refuge. The mountains have also been home to ethnic minorities who notably lived apart from the Khmer culture of the lowlands and were seen as "savages" and taken as slaves in Angkorian times (Zhou Daguan in Harris 2007:61).

Since 2003, we have undertaken a project to geo-locate, survey, and complete radiocarbon dating for an unusual mortuary ritual found in the Cardamom Mountains. Ten sites have now been identified, which range over $\sim 72 \mathrm{~km}$ in a NE by SW line in the eastern range of the Cardamom Massif. We report here on the ${ }^{14} \mathrm{C}$ dating now completed from 4 of the sites: Khnorng Sroal, Phnom Pel, Damnak Samdech, and Khnang Tathan. The ritual practice used large ceramic storage jars and log coffins to contain skeletal remains, which were placed on rock ledges or overhangs. The 50-53-cm-high ceramic jars used for the burials are from the Singburi/Maenam Noi kilns, which were in production as early as the 14th to perhaps the 16th centuries AD (Brown 2004; Shaw 2009:31-2; Grave and Maccheroni 2009:201). The jars have a simple linear decoration on the shoulders, the addition of 4 looped elements, and glazing that stops short of the base. The exception in the use of Maenam Noi jars is that in every site there is always at least one $\sim 45$-cm-high ceramic Angkorian-period jar ( $\sim 12-$ 13th century AD; Cort et al. 2000) as well. Additional tradeware ceramic jars, bowls, and dishes are also found on the ledges and may have been used for food offerings. All of the burial jars appear to have been prepared by breaking away the rim to facilitate the emplacement of larger skeletal material such as entire skulls. A hole was drilled through the bottom of each jar, perhaps to ritually "kill" the vessel. The log coffins in the Phnom Pel, Damnak Samdech, and Khnang Tathan sites are made of an as yet unidentified tree species, which is extremely dense and has a fine annual growth structure. The coffins vary in overall length between 90 to $178 \mathrm{~cm}$, but their design is generally similar in that whole logs are cut into sections, the centers are carved out in squared corners, and each is topped by a lid, but there is no additional carving or decoration to the exterior. The exception to this, at one of the oldest sites, Khnang Tathan, is a single coffin of $210 \mathrm{~cm}$, which has deep chevron carving on the ends of the coffin lid.

Marie Martin, an ethnographer of Cardamom tribal groups in the 1970s, provides us with the first, if brief, mention of these burial sites in Western literature. Martin and fellow French ethnographers Roland Mourer and Jean Ellul heard stories of "bones in caves" in the mountains (Martin 1997:22). And so remained the scant awareness of the sites until March 2000 when the Kingdom of Cambodia set up the Cardamom Conservation Program (CCP). Forest rangers with the CCP reported the discovery of stoneware jars containing bones in a series of sites situated on rock ledges scattered over higher elevations around the massif. The Ministry of Culture and Fine Arts (MoCFA) of the Royal Government of Cambodia commissioned a survey of the jar burial sites, which was completed in March 2002 by Mr Somreth Siphoeun in collaboration with CCP, the Department of Wildlife, and Ministry of Agriculture, Forestry, and Fisheries. The GPS positions of many of those sites appear to have been misfiled and essentially lost. In 2003, the National Geographic Channel underwrote visits by our colleagues Dr Rethy K Chhem, Dr John Miksic, and Mr Somreth Siphouen to 4 of the sites for which there were GPS locations, and one of us (NB) completed the first ${ }^{14} \mathrm{C}$ dating of bone from the site Khnorng Sroal. Subsequent fieldwork has been undertaken by us since 2003 to relocate and record GPS positions for a total of 10 sites (Figure 1). We have now completed full surveys at 2 of the sites (Phnom Pel and Okie, the latter of which had no material for dating), and provisional recording of the ceramics and artifacts, and sampling for ${ }^{14} \mathrm{C}$ dating from a further 3 sites (Khnorng Sroal, Damnak Samdech, and Khnang Tathan). 
Exposed jar and coffin burials have been recorded elsewhere in Mainland and Island Southeast Asia. Some are of great antiquity, while other examples are as late as the 19th century AD. In Thailand, the exposed coffin burial sites of Tham Lod and Ban Rai in the Mae Hong Son province are ${ }^{14} \mathrm{C}$ dated to between $2080 \pm 60$ and $1240 \pm 90 \mathrm{BP}$ (Hotchkis et al. 1994:23; Wannasri et al. 2007:48, no lab numbers provided). The Ongba cave coffins in Kanchanaburi Province are of similar age (2180 \pm 100 BP; K1300; Sørensen 1973:139). In northern Vietnam, a group of quite deteriorated exposed coffins were discovered in the Lung Mu caves, in a Thai ethnic community of Hoi Xuan Commune, Thanh Hoa Province, but no direct dating has been reported for them. In the Xieng Khuang Province in Laos, the same region as the famous Plain of Jars, the Muang Sui caves hold badly looted and deteriorating coffins; a general survey of the site some $50 \mathrm{yr}$ ago is the extent of research (Horr 1959:2-3). In Island Southeast Asia, there is an extensive practice of exposed coffin burials, and in Borneo and Sulawesi, of wooden burial structures (Bellwood 2007:151-2). In the Niah cave sites of Sarawak, Tom Harrisson identified both jar burials and boat-type coffins in several locations (Harrisson 1962) and embarked on a sophisticated plan for the dating of coffin wood, including an estimation of inbuilt age. The direct dating of 1 site that produced a calendar date age range of between AD 891 and 1117 was thought to be in good agreement with associated ceramic tradeware and Chinese coins (Table 2, Figure 8; Szabo et al. 2008:159-60). The Agop Batu Tulug caves in the Kinabatangan Valley, east Sabah, have hundreds of hardwood coffins estimated to be between 700 and 900 BP. In the Philippines, human remains placed in hollowed tree trunks in the Kabayan caves of northern Luzon may be $\sim 400-500 \mathrm{yr}$ old, and the Lungun Cave in Palawan holds a boat-coffin set on a cliff ledge and estimated to be 13th or 14th century, as are the coffins of the Kuruswanan Ledge, which have associated Yuan Dynasty ceramics (Mouret 2000, 2004).

Exposed jar burials holding secondary burial of bone rarely occur in Mainland Southeast Asia. The Tam Nang An Cave, Luang Prabang Province, northern Laos, yielded a ${ }^{14} \mathrm{C}$ age of $1010 \pm 50 \mathrm{BP}$ (OZD 769) for human bone from the single exposed burial jar (Sayavongkhamdy and Bellwood 2000:103). In the Tak Province between Thailand and Burma, exposed jar burial sites are associated with the Lawa hill people, and the 14th-16th centuries $\mathrm{AD}$ age of the sites is inferred from associated Chinese blue and white ware and Burmese and Sawankaloke ware (Shaw 1985:93-102, 1986: 10-3; Pitiphat 1992:11-5). But while the Tak sites are contemporaneous with those of the Cardamom Mountains, the former are of cremated bone. In Island Southeast Asia, jar burials of exposed and interred types are predominant in eastern Indonesia from $\sim 1000 \mathrm{BC}$ and continue to as late as the 19th century AD (Bellwood 1976:254-84, 290). However, we consider here only the occurrence and ages for exposed-type jar burials. In the Philippines, the Tabon caves jar burials are $\sim 1$ st millennium BC (Fox 1970); those of the Seminoho rockshelter and the Cotobato Highland jar burials of southern Mindanao could date to AD 600 (Kurjack and Sheldon 1970, 1971). The Minahasa (North Sulawesi, Indonesia) stone burial jars carved with European-costumed figures, and associated Chinese ceramics, infer a $\sim$ AD 1500 period (Bellwood 1976:254). Exposed burials using stoneware jars in Borneo's Kelibit Highlands and in Berawan may date to about the 14th-16th centuries AD, and aspects of the ritual form are still used in modern funeral rites (Harrisson 1962, 1974; Metcalf and Huntington 1991:74-83).

These examples provide a brief overview of the prevalence, wide geographical range, and chronologies of exposed burial rituals in the Southeast Asian region, and that these are the ritual practices of highland cultures. The Cardamom Mountains jar and coffin rituals are also likely those of highland peoples, and they are distinctive compared with what is known of lowland mortuary practices in the pre-Angkorian and Angkorian periods. In Paul Pelliot's study of Chinese chronicles on Funan, a 1st to 7th century AD polity in the Mekong Delta region, 4 types of mortuary practice were noted: burial by disposal in fast moving rivers; cremation, inhumation in pits; and leaving the body to be 
eaten by wild animals (Pelliot 1903:270). At Angkor Borei, a site on the Mekong Delta of southern Cambodia where the earliest Khmer inscriptions were found, the inhumations of Vat Komnou cemetery are ${ }^{14} \mathrm{C}$ dated to between $2270 \pm 60 \mathrm{BP}$ (WK8948; 420-160 cal BC at $2 \sigma$ ) and $1740 \pm 60 \mathrm{BP}$ (WK-8944; cal AD 130-430 at $2 \sigma$ ) (Stark 2001: Table 1:29). The Oc Eo culture of the southern Mekong Delta has produced only cremation graves that date to the 3rd to 6th centuries AD (O'Reilly 2007:105-6). In the 13th century, Zhou Daguan, a Chinese diplomat visiting the Angkor kingdom, remarked on types of burial he knew of:

"When people die there are no coffins. The body is just kept on a kind of bamboo mat covered by a cloth... (the) body is carried out of the town to a remote, uninhabited spot where it is thrown down and left. After that, vultures, crows and dogs come and eat it...(n)owadays there are also more and more cremations, mainly of the offspring of Chinese," and, "The kings are still buried in towers, though I do not know if their corpses are buried, or just their bones" (Zhou Daguan as translated by Harris 2007:66-7).

There are no further historical references available on mortuary rituals in the Angkorian or postAngkorian period, and little archaeological work has been undertaken on post-Angkorian sites. There is a ${ }^{14} \mathrm{C}$ age of $324 \pm 30 \mathrm{BP}$ (NZA25613) on cremated remains from the post-Angkor temple Kuk Patri with over 200 cremation urns (N Beavan, unpublished data). The calendar date range for the ${ }^{14} \mathrm{C}$ age is cal $\mathrm{AD} 1465$ to 1648 , and indicates that cremation was an ongoing practice in the postAngkorian era.

With regard to the Cardamom Mountain sites, we acknowledge that the challenge with exposed burials is that there is no stratigraphy, nor can we securely draw conclusions from aspects such as the arrangement of the burial receptacles or their contents in a site. For example, the incidence of comingled remains, the number of jars or coffins, and even the arrangement of these receptacles may be compromised by human or animal disturbance. The data we can control is the isotopic analysis and the ${ }^{14} \mathrm{C}$ dating of the remains in each site. Our developing theory about this completely distinctive burial ritual in these highland sites is, in part, based upon its timespan. The reliability of our ${ }^{14} \mathrm{C}$ age determinations is important, and we therefore stringently examine the reliability and consistency of our direct dating results.

\section{METHODOLOGY}

Samples for ${ }^{14} \mathrm{C}$ analysis from the 4 sites include coffin wood, tooth enamel, and human bone. The samples from the various sites have been processed at different times and at different ${ }^{14} \mathrm{C}$ dating facilities over the past 8 years of the project. Sample preparation for each material type, and the institutions undertaking the ${ }^{14} \mathrm{C}$ analysis, are as follows.

\section{Wood}

Each coffin at Phnom Pel was fashioned from a 78 to $87 \mathrm{~cm}$ length cut from a whole log. While the actual species as yet is not identified, it is an angiosperm, and possibly Dipterocarp. We cannot be certain that we have sampled to the bark edge due to the preparation of the logs for coffin building possibly removing part of the phloem-xylem zone. Samples were taken by one of us (BB) from the outermost ring layer, which likely represents sapwood. The coffin at Khnang Tathan was similarly sampled by one of us (TS). We have assumed that the true felling of the trees was within a decade of the conventional ${ }^{14} \mathrm{C}$ age obtained; onsite analysis of the coffins suggests that perhaps as many as 10 rings could have been lost during timber conversion, and we have therefore offset our modeled probabilities by $10 \pm 2 \mathrm{yr}$. 
The wood sample from Khnang Tathan was pretreated at the Australian Nuclear Science and Technology Organisation (ANSTO) to $\alpha$-cellulose using the method of Hua et al. (2004). The pretreated material was converted to graphite using methods described in Hua et al. (2001). The AMS ${ }^{14} \mathrm{C}$ measurements were performed using the ANTARES facility at ANSTO (Fink et al. 2004).

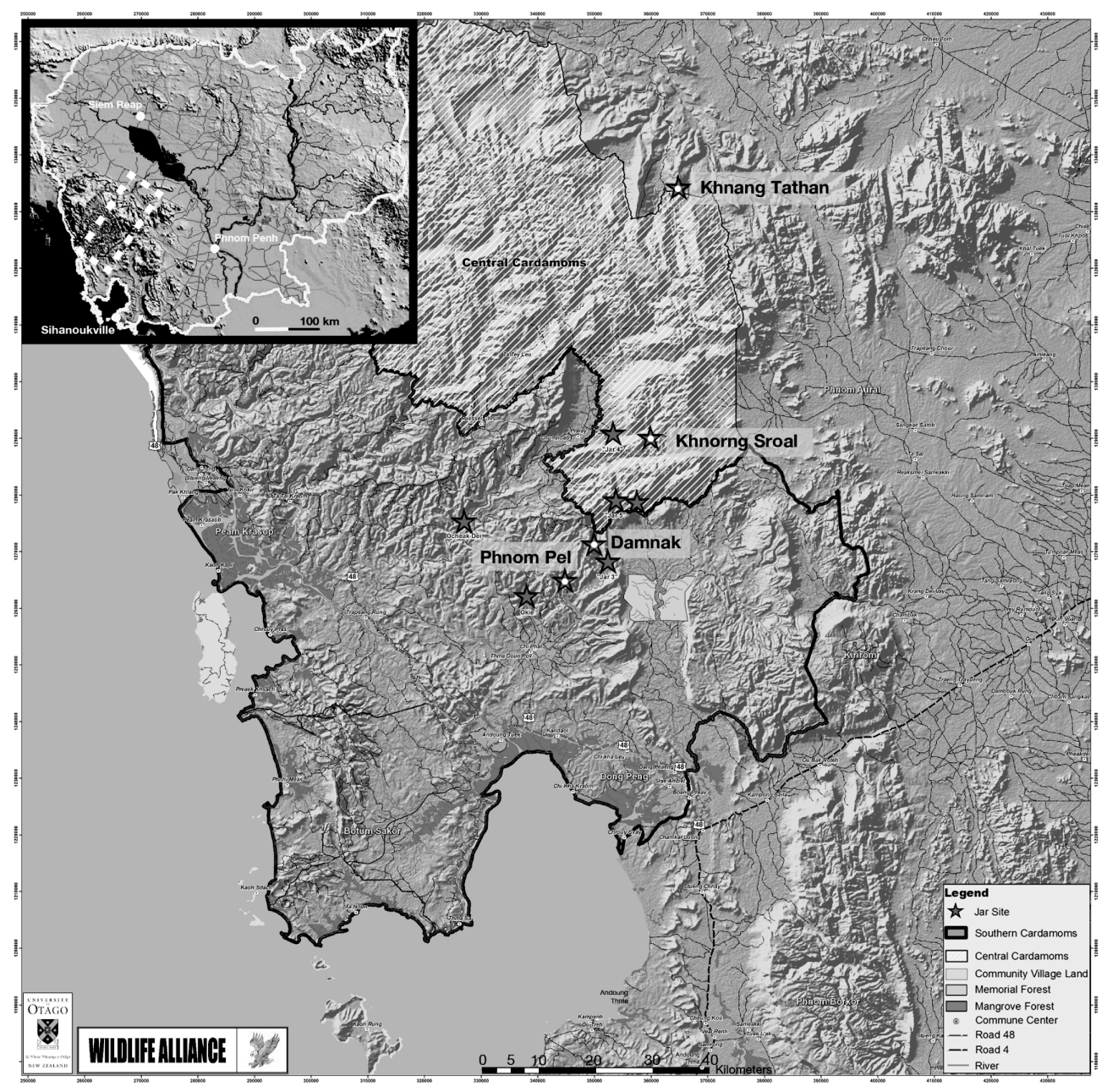

Figure 1 Map of Cambodia and the Cardamom Mountains region. Stars mark all 10 sites that have been geo-located during the project. The 4 sites with ${ }^{14} \mathrm{C}$ results are indicated by a star with a center dot and name label. The straight path distance between the southernmost and northernmost sites is $\sim 72 \mathrm{~km}$. Base map courtesy of Wildlife Alliance (Cambodia).

Wood samples from Phnom Pel coffins were submitted to the Australian National University (ANU), Canberra. Wood was chemically pretreated with an acid/base/acid (ABA) treatment, alternating $1 \mathrm{M} \mathrm{HCl}$ with $1 \mathrm{M} \mathrm{NaOH}$ in 30-min batches until wash solutions were clear, with a final 1-hr $1 \mathrm{M} \mathrm{HCl}$ wash. Samples were then rinsed with Milli- $\mathrm{Q}^{\mathrm{TM}}$ water until neutral and dried overnight. A standard procedure for sample combustion and $\mathrm{CO}_{2}$ purification followed, then graphitization using the method of Santos et al. (2004). ${ }^{14} \mathrm{C}$ analysis was performed using the single-stage accelerator mass spectrometer at ANU (Fallon et al. 2010). 


\section{Replicate Coffin Wood Analysis}

Several of the coffin wood samples analyzed at ANU produced $\delta^{13} \mathrm{C}$ values that were more depleted than expected, in the area of $-29 \%$. To examine what effect, if any, these lower ${ }^{13} \mathrm{C}$ values had on the measured age, 3 replicate samples (Phnom Pel coffins 7, 8, and 9) were submitted for ${ }^{14} \mathrm{C}$ dating to the Scottish Universities Environmental Research Centre (SUERC). The samples were prepared to $\alpha$-cellulose following the Belfast protocol (Hoper et al. 1998), combusted to carbon dioxide (Vandeputte et al. 1996), converted to graphite (Slota et al. 1987), and then measured as described by Xu et al. (2004). The resultant $\delta^{13} \mathrm{C}$ values after following the $\alpha$-cellulose pretreatment $(-25 \%)$, are closer to that expected for wood. Furthermore, the SUERC and the ANU ${ }^{14} \mathrm{C}$ results are statistically similar, even though the former used an $\alpha$-cellulose treatment and the latter an ABA treatment. The original and replicate results for each of the Phnom Pel coffins 7, 8, and 9 are thus combined and shown in Table 1 as a weighted mean following the method of Ward and Wilson (1978).

\section{Bone}

Approximately 200-mg samples of bone were taken from each individual. Samples from Phnom Pel were taken from the best preserved of the femur or tibia bones available. Khnorng Sroal samples came from 1 rib (no sex determined), and from the temporomandibular joints on 2 mandibles from skulls $\mathrm{C} 3$ and $\mathrm{C} 8$, who were both male. Bone samples were pretreated according to a modified Longin method given in Beavan-Athfield et al. (2001), with an additional molecular weight separation at $30 \mathrm{kD}$ (see Woodman and Beavan-Athfield 2009; Hurst et al. 2010) to aid in the removal of humic acid contaminants, and to concentrate the best preserved protein. The molecular weight separation filters were precleaned according to the regimen described in Brock et al. (2007). The pretreated bone protein samples from Phnom Pel were submitted to the ANU laboratory for ${ }^{14} \mathrm{C}$ analysis and the samples of pretreated bone protein from Khnorng Sroal were analyzed at the GNS Science (New Zealand) accelerator facility.

\section{Tooth Enamel}

An incisor from Phnom Pel and an M2 molar from Damnak Samdech were first physically cleaned, washed in deionized water, and dried. Tooth enamel was then chipped from dentine cores for chemical preparation and carbonate evolution. Samples were pretreated with a $0.5 \mathrm{M} \mathrm{HCl}$ acid wash, then rinsed with deionized water, dried, and pulverized to $0.75 \mu \mathrm{m}$. Acid hydrolysis was performed on the pretreated enamel $\left(\mathrm{CO}_{2}\right.$ evolution) in a process where the powdered enamel was loaded into high-vacuum reaction vials, and then evacuated before $\mathrm{CO}_{2}$ was liberated by introduction of $85 \%$ orthophosphoric acid. The $\mathrm{CO}_{2}$ was cryogenically distilled and transferred to Pyrex ${ }^{\circledR}$ tubes with $\mathrm{CuO}$ and silver wire, and then combusted at $900{ }^{\circ} \mathrm{C}$. The gas was then cryogenically distilled and graphitized for ${ }^{14} \mathrm{C}$ analysis by the method of Santos et al. (2004) at the ANU laboratory (enamel from Phnom Pel); and by the method of Hua et al. (2001) at the ANTARES facility at ANSTO (enamel from Damnak Samdech).

\section{Beading String}

A fragment of fibrous string was found caught in a bead within Coffin 11 at Phnom Pel. The string was pretreated by an acid-base-acid method and combusted, graphitized and analyzed as previously described for wood samples run at the ANU accelerator facility. 


\section{RESULTS}

The $28{ }^{14} \mathrm{C}$ measurements (including Phnom Pel coffins 7, 8, and 9 wood replicates) from the 4 sites are presented in Table 1. The conventional radiocarbon ages (CRAs; Stuiver and Polach 1977) are quoted according to the international standard set at the Trondheim convention (Stuiver and Kra 1986). The corresponding calendar date ranges have been calculated using the maximum intercept method (Stuiver and Reimer 1986), quoted in the form recommended by Mook (1986) with the endpoints rounded outward to $10 \mathrm{yr}$ where the error is $25 \mathrm{yr}$ or greater, and to $5 \mathrm{yr}$ where it is less than 25 yr. The probability distributions (Figures 2 and 3) were obtained by the probability method (Stuiver and Reimer 1993), with calendar date ranges calculated using OxCal v 4.1 (Bronk Ramsey 2009), and the internationally agreed curve for the Southern Hemisphere (SHCal04) (McCormac et al. 2004). The use of the Southern Hemisphere curve follows recent research by Hua et al. (2004) on a Thai dendrochronological database. There is a ${ }^{14} \mathrm{C}$ age offset for Thailand due to a mixing of Northern Hemisphere and Southern Hemisphere air masses, and, relative to SHCal04, the weighted average of the offset for Thailand for between AD 1620 and 1780 is $-21 \pm 6 \mathrm{yr}$ (Q Hua, personal communication, 25 November 2011). The calibration curve in this examination of Cambodian materials has used SHCal04 with an offset of $-21 \pm 6 \mathrm{yr}$.

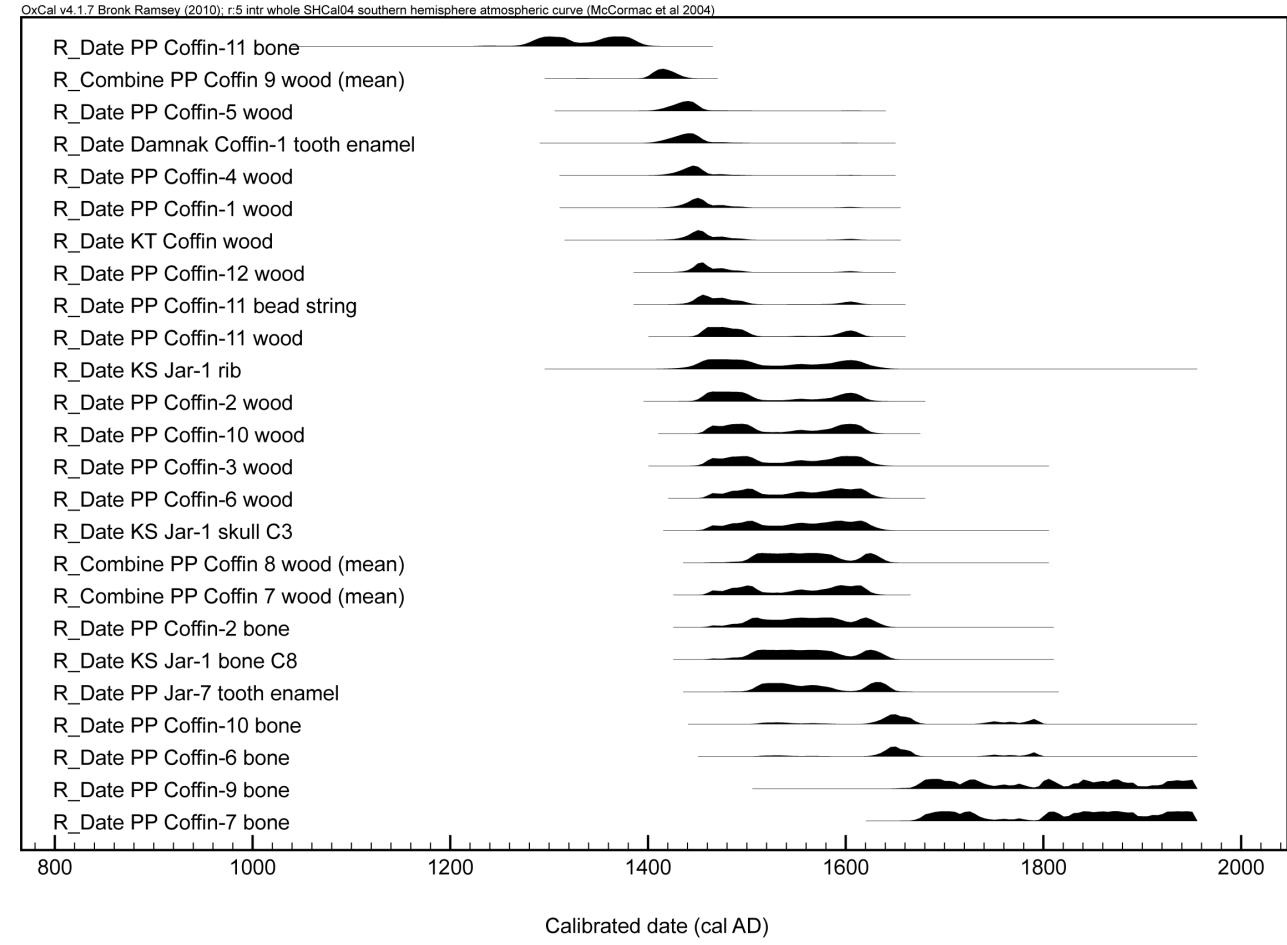

Figure 2 Calibrated CRAs for human bone, tooth enamel, and coffin wood from Phnom Pel (PP), Khnorng Sroal (KS), Damnak Samdech, and Khnang Tathan (KT) sites.

In general, the ${ }^{14} \mathrm{C}$ ages in Table 1 that we consider the most reliable from the 4 sites fall between 330 and $565{ }^{14} \mathrm{C}$ yr BP. Simple calibration indicates that all 4 sites were in use from the beginning of the 15 th century AD until the first half of the 17 th century AD. While a subjective analysis of the calibrated dates does provide a starting point for understanding a site's chronology, sophisticated 


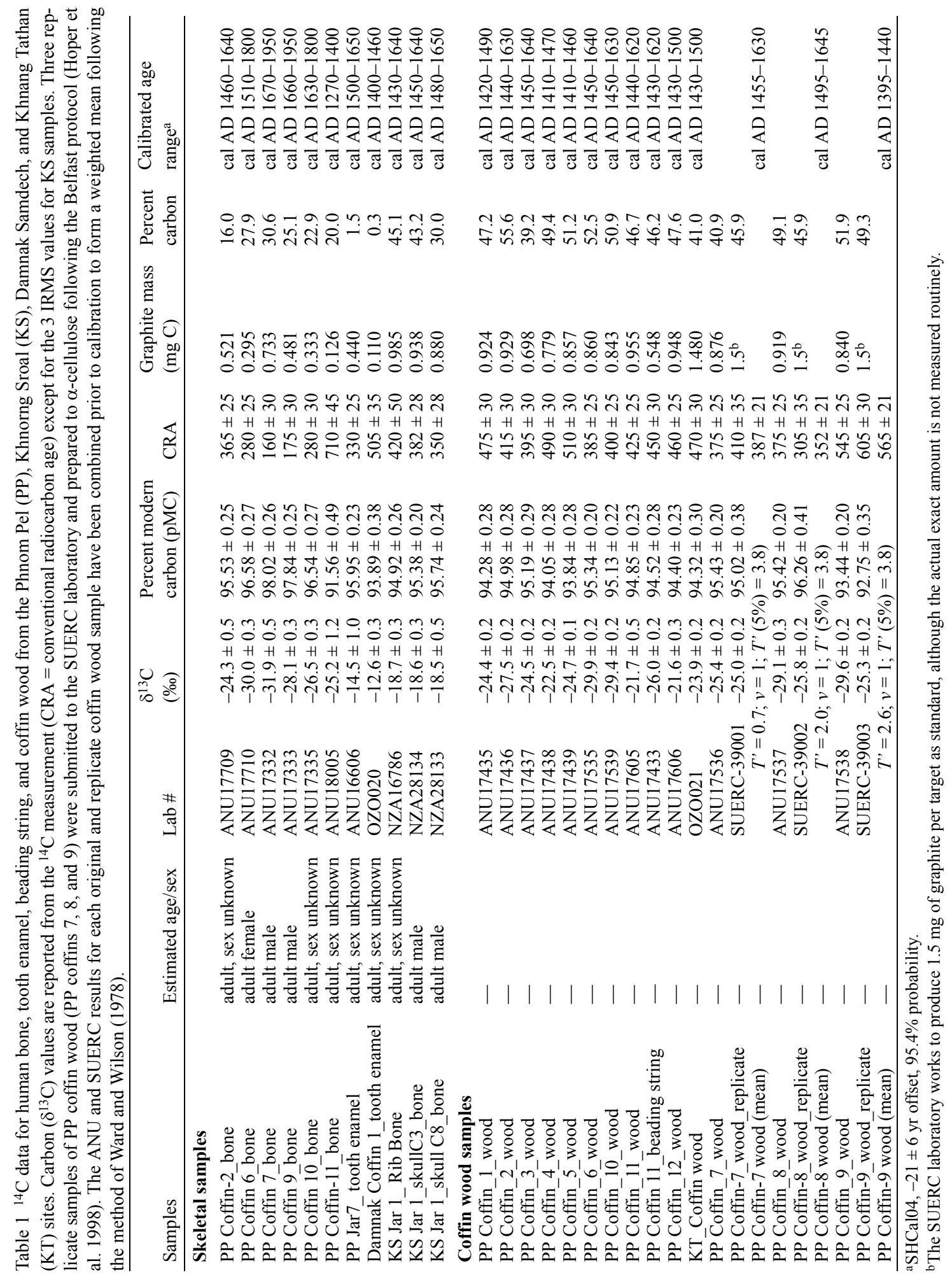




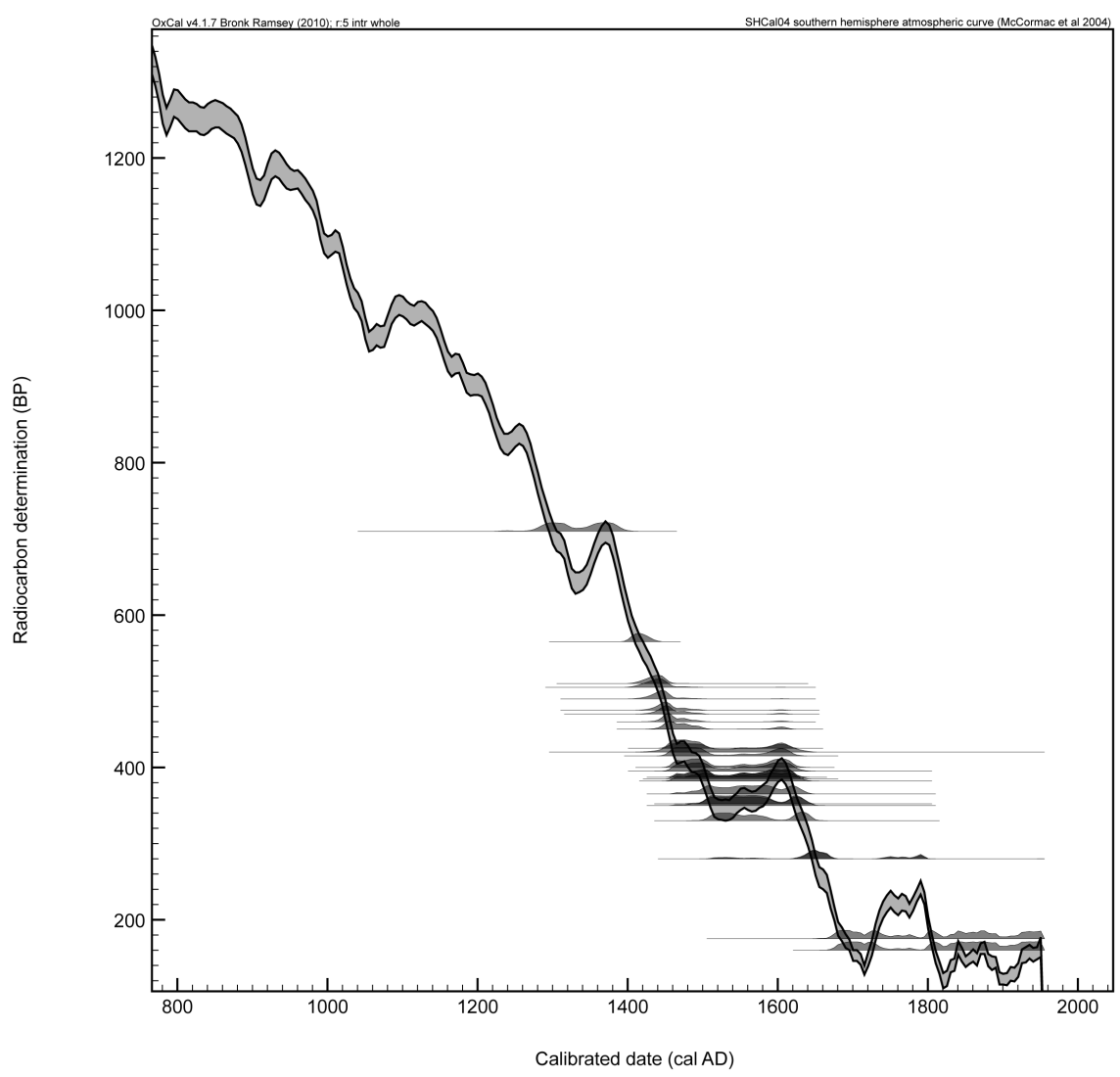

Figure 3 Calibrated dates for all of the CRAs from the Cardamom jar and coffin burials listed in Table 1 and shown in Figure 2, plotted against the offset SHCal04 calibration curve. Note that the shape of the calibration curve creates broad calendar date ranges for several of the results.

analytical tools are at our disposal for constructing what we consider to be a more robust chronology from the suite of results. Accordingly, in our discussion of the Phnom Pel results, we present a Bayesian treatment of the ${ }^{14} \mathrm{C}$ ages for our largest sample set, which are the 12 coffins.

Some of the ${ }^{14} \mathrm{C}$ results were subject to scrutiny. For example, in the Phnom Pel site, there is 1 human bone (Coffin-11) with a CRA of $710 \pm 45 \mathrm{yr}$ BP and a $\delta^{13} \mathrm{C}$ of $-25.2 \%$ (ANU18005, Table 1). This CRA is an older outlier, which could indicate a reburial of bones. The source of the bones is possibly another coffin, fragments of which were nearby, but we could not obtain a wood sample on that coffin due to the degree of decay marring a clear ring structure. At the younger end of the range, between 160 and $280{ }^{14} \mathrm{C}$ yr BP, there were 3 outliers of human bone from coffins 6,7 , and 9 (ANU17710, ANU17332, ANU17333; Table 1). We suspect that, despite the use of molecular weight filtration in the processing, humic acids have contributed to the younger ages, a suspicion that is backed by the $\delta^{13} \mathrm{C}$ results. The reported stable carbon values in Table 1 were determined during the accelerator mass spectrometry (AMS) analysis, which may be offset by as much as $2-3 \%$ from that of an isotope ratio mass spectrometry (IRMS) measurement. Low sample yields of bone protein from Phnom Pel did not allow for separate IRMS analysis of $\delta^{13} \mathrm{C}$ (or for $\delta^{15} \mathrm{~N}$ ), and therefore, we can only generalize as to what the available carbon values might indicate. The human bones from coffins 6,7 , and 9 are associated with $\delta^{13} \mathrm{C}$ values of between $-28.1 \%$ and $-31.9 \%$, a range 
that is significantly more depleted than would be expected even if the individuals had consumed a fully terrestrial vegetable diet, which would average about $-22 \%$ in human bone. It is entirely possible that the association of the younger ages with the most depleted $\delta^{13} \mathrm{C}$ is due to contamination by exogenous carbon (Figure 4). However, the $\delta^{13} \mathrm{C}$ results for human bone from Coffin $2(-24.3 \%$ ), and Coffin $10(-26.5 \%)$ are also beyond the expected human terrestrial diet range even when considering the possible AMS $\delta^{13} \mathrm{C}$ offset, but the CRAs of the bones fit well into the overall timespan for the Phnom Pel site.

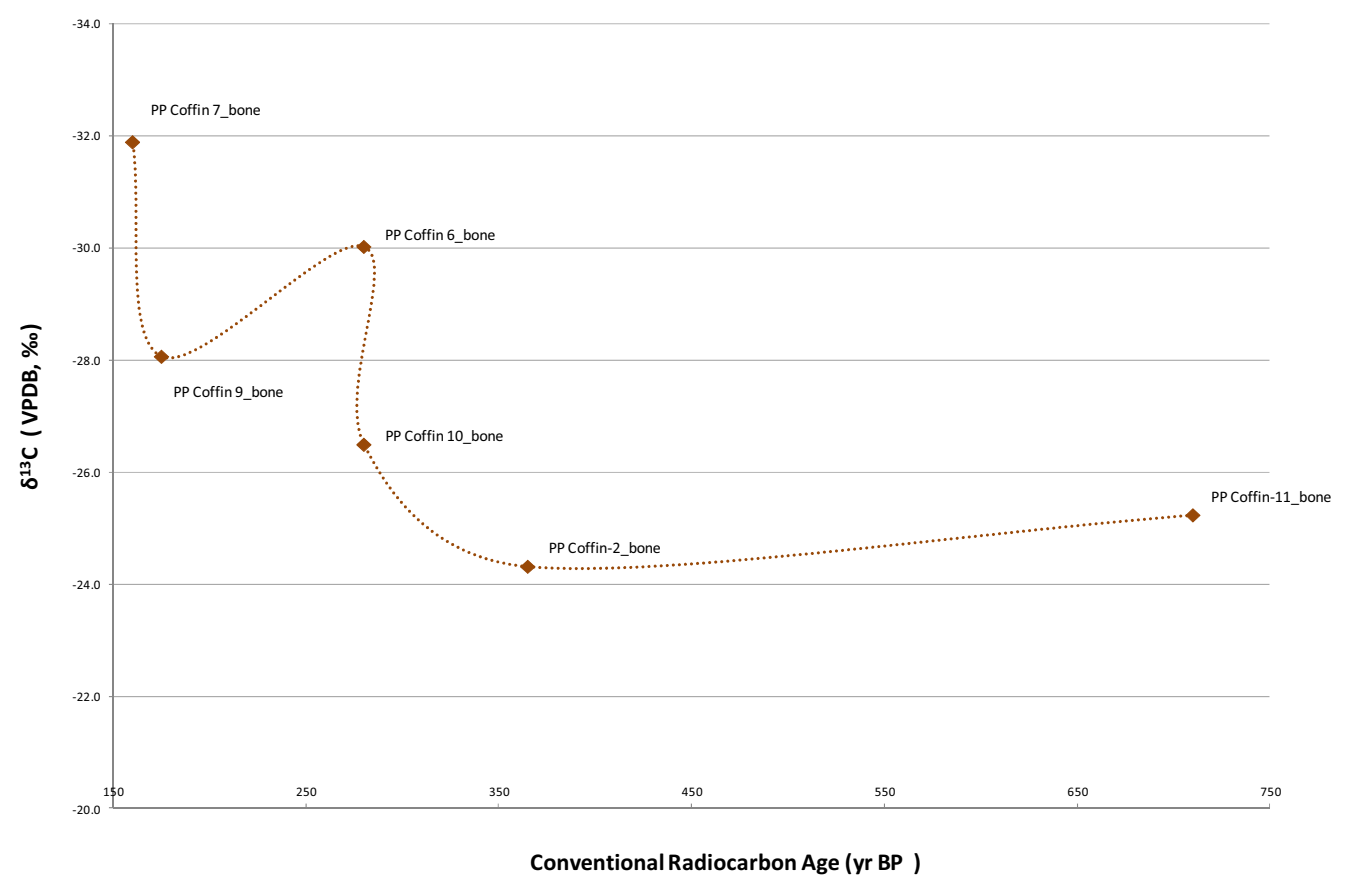

Figure 4 Conventional radiocarbon ages (CRAs) on bone from the Phnom Pel coffins versus $\delta^{13} \mathrm{C}$. The youngest ages are associated with increasingly depleted $\delta^{13} \mathrm{C}$. The association is possibly due to contamination by exogenous carbon, despite the use of molecular weight separation to filter the bone protein.

After considering the overall timespan for the burial ritual as indicated by the collated ${ }^{14} \mathrm{C}$ results from all 4 sites, we now turn to examining the ${ }^{14} \mathrm{C}$ results from the individual sites.

\section{Khnorng Sroal}

The first ${ }^{14} \mathrm{C}$ dates for the Cardamom Mountain burial ritual were obtained in 2003 for the Khnorng Sroal site as part of a National Geographic documentary. The site is a south-facing natural rock ledge on a lightly forested hillside at $711 \mathrm{~m}$ asl. The site was composed of 3 intact Maenam Noistyle ceramic jars holding comingled skeletal remains, 2 Maenam Noi jar bases, and a number of associated pottery shards. The pottery included 2 non-local shards: a fragment of Chinese stoneware jar with yellowish glaze and incised linear decoration, and a piece of a green Sisatchanali bowl of possibly the 15th century AD (cf. Brown 2004:77-8).

We have both IRMS stable isotope analyses and ${ }^{14} \mathrm{C}$ dating for 3 bone samples, 1 rib, and 2 adult male skulls (C3 and C8), from the "Jar 1" burial at Khnorng Sroal. Carbon and nitrogen percentages in the samples indicated the bone was well preserved (atomic $\mathrm{C} / \mathrm{N}$ ratios were 3.3 to 3.2 ). The $\delta^{15} \mathrm{~N}$ 

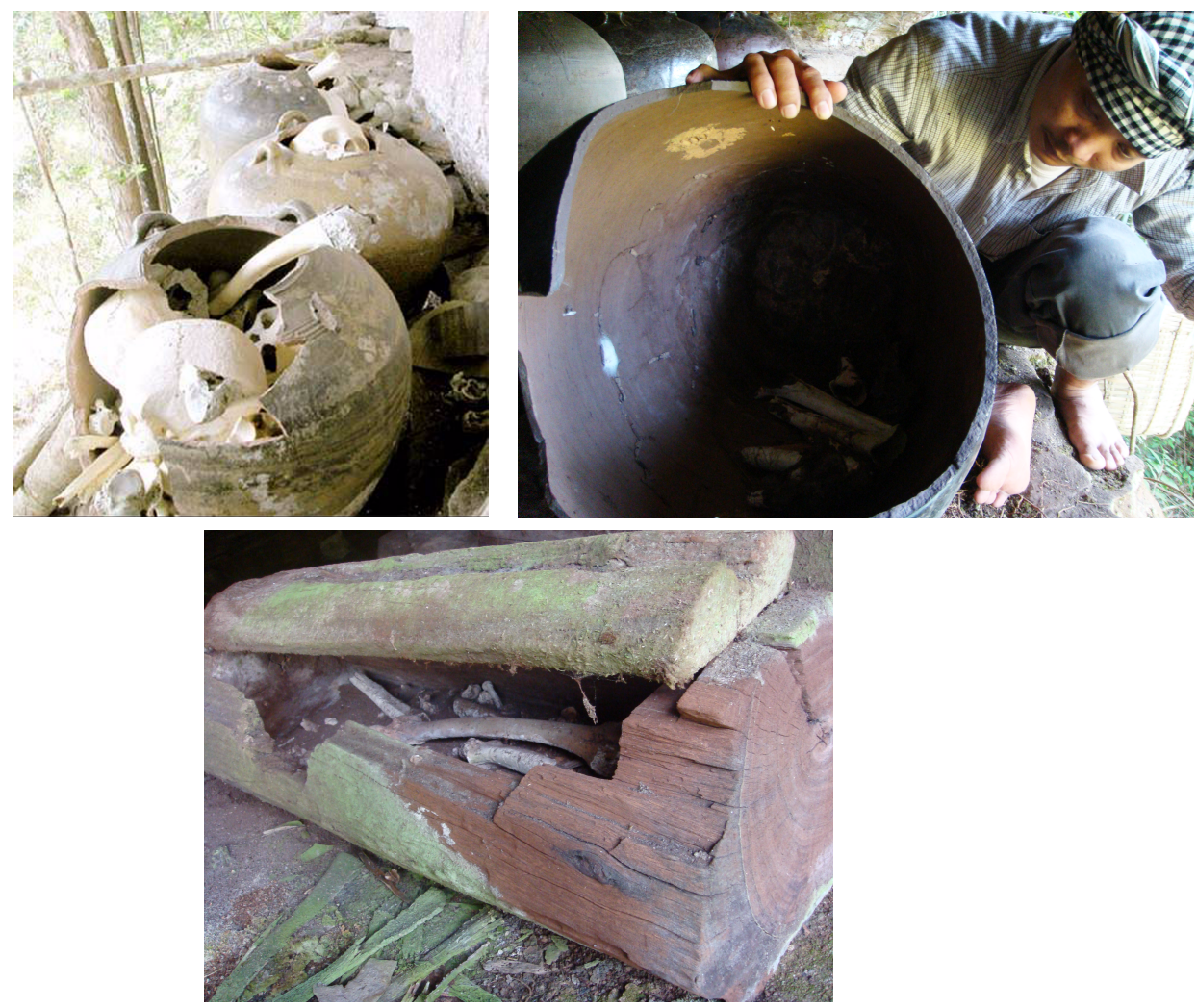

Figure 5 a) Jar Burial, Khnorng Sroal; b) Jar Burial Phnom Pel; c) coffin burial Phnom Pel

values for the bones, from $9.2 \%$ to $11.8 \%$, suggest a diet with a high consumption of animal- or fish-based protein. The $\delta^{13} \mathrm{C}$ values of $-18.7 \%$ to $-18.5 \%$ were also slightly enriched, and a $\delta^{34} \mathrm{~S}$ analysis of the rib bone (NZA16786) was therefore obtained to investigate possible marine influences to diet. The $\delta^{34} \mathrm{~S}$ result of 5.3\% was similar to the inland continental terrestrial value range for plants (2\%o to 6\%o, Peterson and Fry 1987:304). After a simple back-calculation based on the enrichment of $\delta^{34} \mathrm{~S}$ of $0.5 \%$ by trophic level, the $\delta^{34} \mathrm{~S}$ value for the bone is indicative of an individual with a diet based on inland terrestrial foods and, therefore, the ${ }^{14} \mathrm{C}$ ages would not be affected by a marine offset. This result, however, does not exclude the possibility that the slightly enriched nitrogen values are due to consumption of freshwater fish from the numerous rivers and lakes in the region and the enriched carbon values could be contributed by local $\mathrm{C}_{4}$ plant foods.

A chi-square test (Ward and Wilson 1978) of the 3 Khnorng Sroal ${ }^{14} \mathrm{C}$ ages indicates that they are not significantly different $\left(d f=2, T^{\prime}=1.456[5 \%=5.991]\right)$, and that the jar may contain individuals whose bones were interred together within a generation. The calendar date ranges $( \pm 2 \sigma)$ for Khnorng Sroal are between cal AD 1430 and 1650 (Tables 1,2). The associated burial goods, which included 15th-16th century AD Thai Sisatchanali porcelains and 14th-16th century AD Maenam Noi ceramic jars (Grave and Maccheroni 2009:201) used as burial receptacles for bone, support the conclusion that the ${ }^{14} \mathrm{C}$ ages from the site give an accurate indication of when the objects on the rock ledges were placed there (Figure 6). 
Table 2 Stable isotope and ${ }^{14} \mathrm{C}$ results from human bone samples from Jar 1 at Khnorng Sroal. Stable isotope results for the 3 bone samples are indicative of diets relatively rich in animal protein, but, as suggested by the terrestrial range for $\delta^{34} \mathrm{~S}$ of the rib bone (NZ16786), the enrichment of $\delta^{13} \mathrm{C}$ and $\delta^{15} \mathrm{~N}$ is not associated with marine resources, which would have affected the apparent age.

\begin{tabular}{|c|c|c|c|c|c|c|c|}
\hline Lab nr & Sample & $\begin{array}{l}\delta^{13} \mathrm{C} \\
(\%)\end{array}$ & $\begin{array}{l}\delta^{15} \mathrm{~N} \\
(\%)\end{array}$ & $\begin{array}{l}\delta^{34} S \\
(\%)\end{array}$ & $\begin{array}{l}\text { Atomic } \\
\mathrm{CN}\end{array}$ & $\begin{array}{l}\text { Conventional } \\
\text { radiocarbon } \\
\text { age }(\mathrm{CRA})\end{array}$ & Calendar age $(2 \sigma)$ \\
\hline NZA16786 & Rib bone & $-18.7 \pm 0.2$ & $11.8 \pm 0.3$ & $5.3 \pm 0.2$ & 3.3 & $420 \pm 50$ & AD $1442(95.4 \%) 1629$ \\
\hline NZA28134 & Skull C3 & $-18.6 \pm 0.2$ & $9.2 \pm 0.3$ & nd & 3.2 & $382 \pm 28$ & AD $1464(95.4 \%) 1627$ \\
\hline NZA28133 & Skull C8 & $-18.5 \pm 0.2$ & $9.5 \pm 0.3$ & nd & 3.2 & $350 \pm 28$ & AD $1494(95.4 \%) 1644$ \\
\hline
\end{tabular}

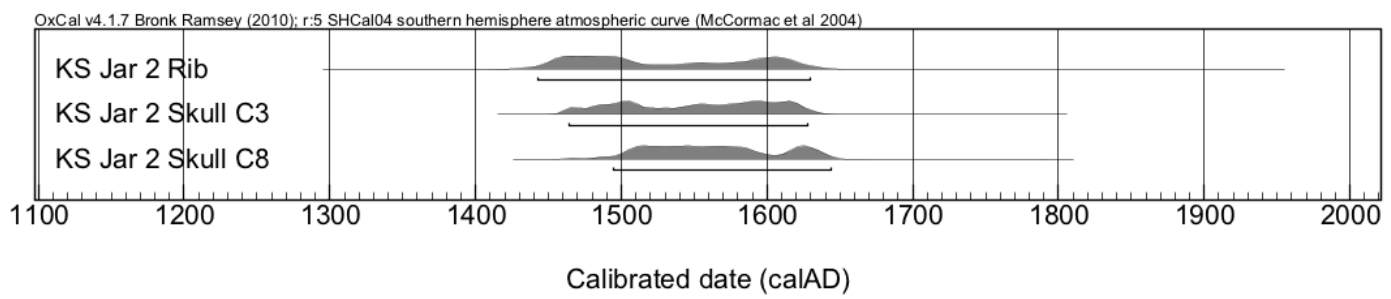

Figure 6 Multiplot of calibrated ${ }^{14} \mathrm{C}$ ages for the Khnorng Sroal bone samples

\section{Phnom Pel}

Some of the ${ }^{14} \mathrm{C}$ results from Phnom Pel were discussed in our overview of the collated ages obtained for all 4 sites, and Phnom Pel accounts for the greatest number of results in our data set. The Phnom Pel site contains the largest number of coffins found in any 1 site, and the most jar burials. The site consists of 3 west-facing rock ledges at $197 \mathrm{~m}$ asl in a thickly forested setting. The 2 ledges at the south end of the site hold a total of 7 Maenam Noi jars, 2 local earthenware pots, and celadon-glazed ceramics including 15th to 16 th century Thai Sawankhalok/Sisatchanali (Brown 2004:146, 149) and 15th-16th century AD Burmese Twante (Tsuda 1999). The third ledge, some $200 \mathrm{~m}$ to the north of the jar ledges, holds a total of 12 intact coffins and the remains of at least 2 additional coffins. The coffins have been fashioned from sections of whole logs, the sides of which have been planed slightly but which still retain what we consider to be complete tree-ring sequences that have perhaps lost only a decade of their ring structure (Figure 7). The coffin interiors were hollowed out, leaving squared interior corners, and the lids for each coffin are shaped in a shallow triangular form, but there is no additional decoration to the coffins. There is no indication of the relative ages of the coffins at Phnom Pel other than the ${ }^{14} \mathrm{C}$ dating. We intend, however, to undertake comparative tree-ring analysis when funding is available. The ${ }^{14} \mathrm{C}$ ages obtained for the coffin wood samples are indicative of at least the time when the trees were harvested to make the coffins.

There were $7{ }^{14} \mathrm{C}$ ages produced for human remains (on bone and tooth enamel) and $15{ }^{14} \mathrm{C}$ ages for the coffin wood samples obtained from the outermost ring-sequence, including replicate analyses of coffins 7, 8 , and 9 (Table 1, Figure 2). As discussed in the Methods section above, the original ${ }^{14} \mathrm{C}$ analyses of coffin wood prepared by the acid/base/acid (ABA) treatment had produced $\delta^{13} \mathrm{C}$ values more depleted (about $-29 \%$ ) than expected. We undertook a second round of analyses using the remaining archived material from coffins 7, 8, and 9 and prepared these by the $\alpha$-cellulose method (Hoper et al. 1998). The $\delta^{13} \mathrm{C}$ values of the wood from each of the samples after the $\alpha$-cellulose pretreatment were less depleted (about $-25 \%$ ) relative to the $\delta^{13} \mathrm{C}$ values of the original analyses of coffins 7,8 , and 9 , but the ${ }^{14} \mathrm{C}$ results for the wood samples after the $\alpha$-cellulose treatment were statis- 

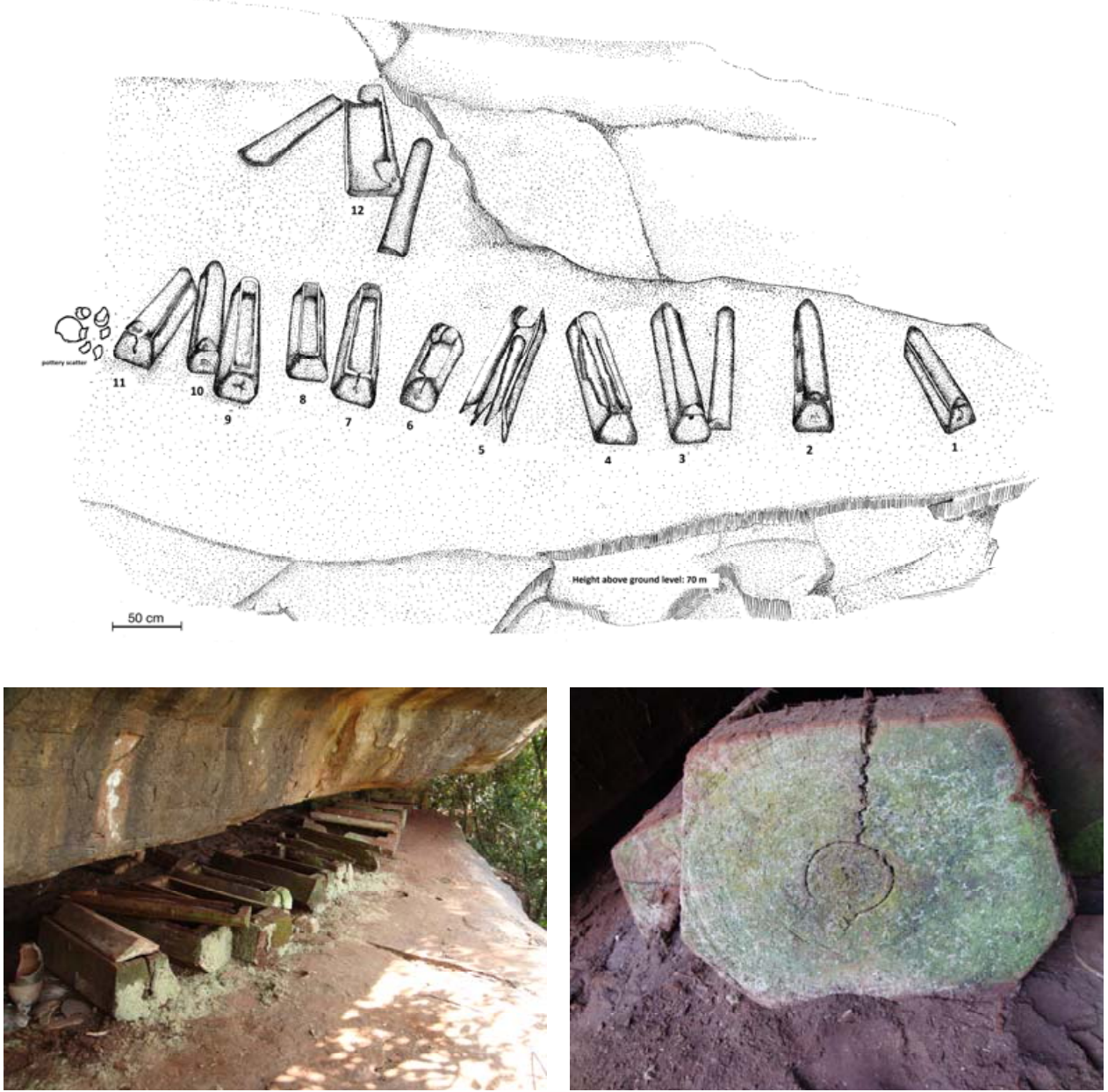

Figure 7 The layout of the coffins on the ledge at Phnom Pel (top and left); and an example of a full ring sequence in coffin wood (right).

tically consistent with the results from the ABA treatment. The original and replicate results for each of the Phnom Pel coffins 7, 8, and 9 were combined and shown in Table 1 as a weighted mean following the method of Ward and Wilson (1978).

An initial cluster analysis of the ${ }^{14} \mathrm{C}$ ages (Wilson and Ward 1981) suggested a 2-group clustering of the coffin ages, with the youngest 7 coffins forming a cluster with a mean and standard deviation of $395 \pm 11 \mathrm{yr}$, and the oldest 5 coffins forming a cluster with a mean and standard deviation of $494 \pm$ $15 \mathrm{yr}$. The clusters may indicate 2 discrete phases of activity associated with harvesting the trees for fashioning the coffins, but they may also result from a distortion of the ${ }^{14} \mathrm{C}$ ages arising from change in the slope of the calibration curve, similar to the calibration stochastic distortion (CSD) effect identified by McFadgen et al. (1994).

The Phnom Pel coffin wood results have been further analyzed using a Bayesian approach (Buck et al. 1996) to model the start and end date of activity, as well as its overall span. By utilizing the archaeological information, and accounting for the statistical scatter inherent in both the ${ }^{14} \mathrm{C}$ dating method and calibration, the Bayesian approach allows for the production of more robust and precise 
chronologies (Bayliss 2009). The methodology is interpretative, but also explicit with regard to the data and prior information that is input. As such, the estimates can change as researchers add new data or choose to model the current data in different ways. For archaeologists, using this approach provides a means through which new questions can be asked about the timing and temporality of archaeological events.

The chronological model was constructed and run with OxCal v 4.1 (Bronk Ramsey 2009). Initially, a chronological model was constructed using all of the available dates from Phnom Pel. Because of the potential problems with the results of human bone analyses at this site as discussed earlier, the final model (Figure 8 ) is constructed using only the ${ }^{14} \mathrm{C}$ measurements from the outer tree rings from 12 coffins, and is used to better estimate the span of the period during which the trees were harvested for coffin production.

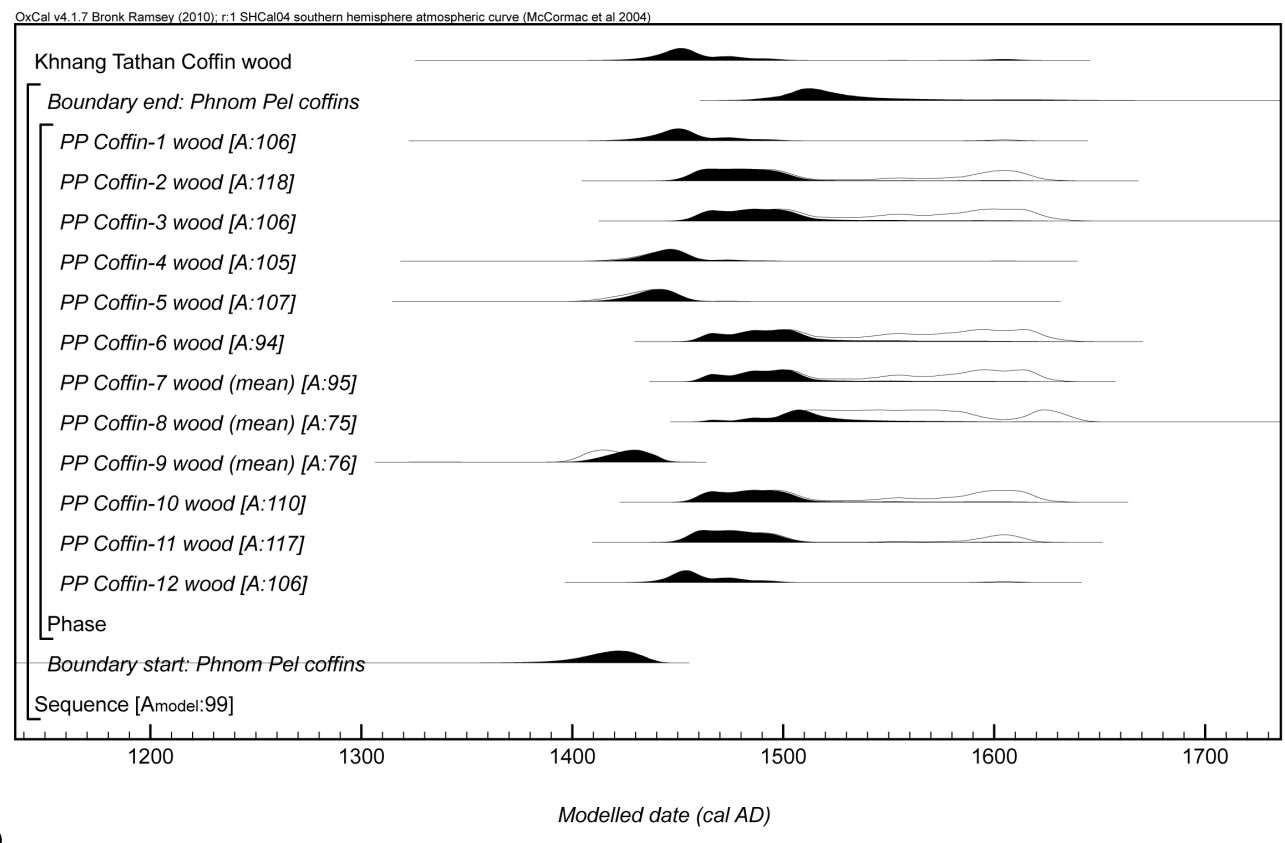

a)

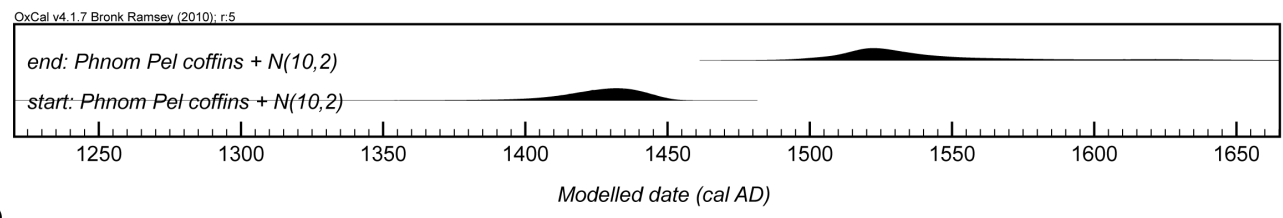

b)

Figure 8 Chronological modelling of the Phnom Pel coffin dates: a) Modeled probability distribution for calibrated ${ }^{14} \mathrm{C}$ ages showing the most likely calendar date range for the manufacture of each coffin. Two distributions are plotted, one in outline, which is the result of simple ${ }^{14} \mathrm{C}$ calibration, and a solid one, which is based on the chronological model. The large square "brackets" along with the OxCal keywords define the overall model exactly. "Khnang Tathan coffin wood" is the calibrated ${ }^{14} \mathrm{C}$ result from that coffin, and is included here as a comparison to the Phnom Pel data; it is not modeled. b) Probability distribution for the start and end of coffin manufacture: start: Phnom Pel coffins is the modeled date that coffin construction began, while end: Phnom Pel coffins is the modeled date that coffin construction ended. An offset of $10 \pm 2 \mathrm{yr}$ has been applied to allow for possible loss of the bark edge layer. 
The results of the Bayesian statistical analysis of the coffin ${ }^{14} \mathrm{C}$ ages (Figure 8a) show good agreement with the archaeological assumption that the construction of the coffins represents a single phase of activity $\left(\mathrm{A}_{\text {model }}=99\right)$. Because the ${ }^{14} \mathrm{C}$ ages are of wood that may be up to a decade or so too old (see above), the modeled results have been offset by $10 \pm 2 \mathrm{yr}$. The offset probabilities for the start and end of activity associated with coffin building at Phnom Pel are given in Figure $8 \mathrm{~b}$. The model estimates that tree harvest for coffin construction began between cal AD 1385-1445 (95\% probability; start: Phnom Pel coffins; Figure 8b) and probably between cal AD 1405-1435 (68\% probability). Coffin construction spanned 55-215 yr (95\% probability; Figure 9), and probably 70$130 \mathrm{yr}$ (68\% probability; Figure 9). Tree harvest ended for the coffins at Phnom Pel between cal AD 1480-1625 (95\% probability; end: Phnom Pel coffins) and probably in cal AD 1495-1540 (68\% probability). Figure $8 \mathrm{a}$ also shows for comparison the unmodeled date from the Khnang Tathan coffin.

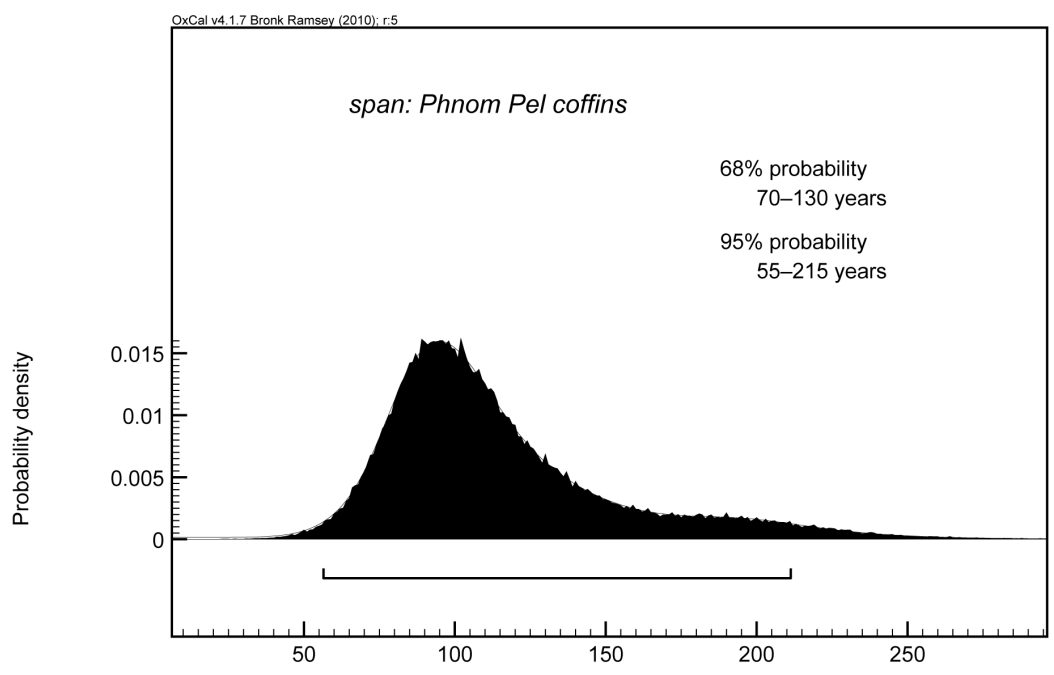

Figure 9 Span of activity associated with the harvest of trees and likely construction of coffins sampled at Phnom Pel. The span is derived from the chronological modeling in Figure 8a,b.

The earliest calendar date for the Phnom Pel coffins is cal AD 1395-1440, from the mean of 2 analyses of Coffin 9 (ANU17538, SUERC-39003). The date is significant as it suggests that the trees for these coffins were harvested in the last century of the Angkor kingdom, and overlaps the $\sim A D 1432$ Thai kingdom of Ayutthaya's last and successful siege of Angkor, and the abandonment of the city. The latest calendar date for Phnom Pel coffins is cal AD 1495-1645, from the mean of 2 analyses of Coffin 8 (ANU17537, SUERC-39002), and shows that the highland ritual was sustained during the same period that saw lowland Khmer polity shift to the Mekong region, the establishment of successive capitols, and interim warfare with Ayutthayan invaders (e.g. the siege and fall of Lovek $\sim$ AD 1593; Dressler 2010:340).

The ${ }^{14} \mathrm{C}$ results from bone at Phnom Pel were less robust, as the skeletal material was badly deteriorated. In addition to typical poor preservation in hot humid conditions, the bones in the jars and coffins were subject to damage from termites, and from contact with bat guano. At the 2 jar ledges, skeletal remains of up to 6 adults and 3 children were found in the Maenam Noi burial jars, but we have only 1 successful direct date for jar burial contents at this site, and that is from human tooth enamel. Tooth enamel provides a material that is resilient in such poor preservation conditions as the 
Phnom Pel site, and has been shown to provide reliable dates (Woodman and Beavan-Athfield 2009; Zazzo and Saliège 2011). The CRA of $330 \pm 25$ BP for the tooth enamel (PPJar7-tooth enamel; ANU16606; Table 1) provides a $2 \sigma$ calendar date range for the Jar-7 burial of cal AD 1500-1650.

We gained perspective on our interpretation of ${ }^{14} \mathrm{C}$ results for bone at Phnom Pel from examples where associated materials produced complementary ages, as well as from sample pairings that are not in agreement. The ${ }^{14} \mathrm{C}$ ages of Coffin 11 wood and a piece of string found in a glass bead from Coffin 11 (425 \pm 25 BP, ANU17605; $450 \pm 30$ BP, ANU17433, respectively; Figures 10, 11) are identical within analysis error. The combined calendar date range for the string and wood is cal AD 1430-1470. This could suggest that the bead necklace may have been placed in a newly made coffin. However, the human bone sample from within Coffin 11 is significantly older than the coffin wood and string ages $(710 \pm 45 \mathrm{BP}$; ANU18005) and provides a $2 \sigma$ calibrated date range of cal AD $1275-$ 1395. Considering the agreement between Coffin 11 wood and the string from a beaded necklace offering, the older age for Coffin 11 bone may possibly be indicative of the placement of older human remains in a newer coffin. We did find the remnants of rotted coffins on the ledge, and these held no bone, nor was there bone scatter in the immediate vicinity.

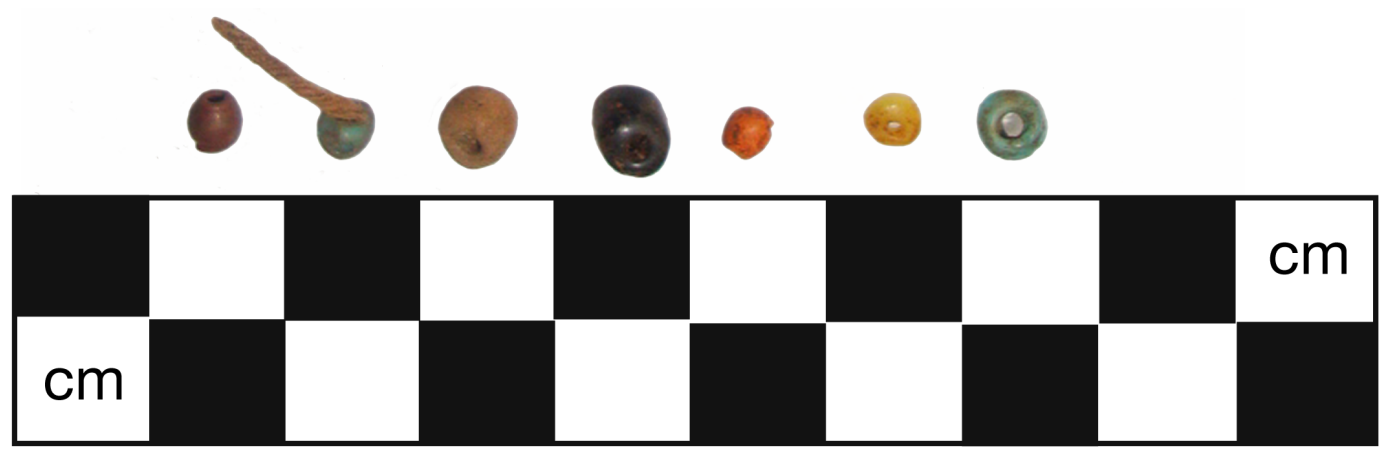

Figure 10 Beads from Coffin 11, with fragment of beading string found in a small turquoise bead (second from left)

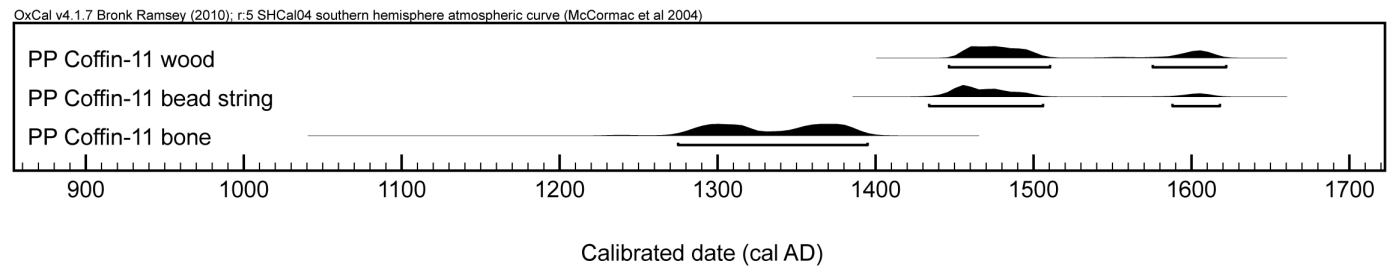

Figure 11 Multiplot of calibrated CRAs for the bone, string within a bead, and coffin wood from Coffin 11 at Phnom Pel

On the other hand, some bone ages that are much younger than their associated coffin had given us reason to doubt the reliability of the ${ }^{14} \mathrm{C}$ ages for those bone samples. In the case of the bones that produced the youngest outliers, i.e. between 160 and $280 \mathrm{yr}$ BP (human bone from coffins 6, 7, 9, 10; ANU17710, ANU17332, ANU17333, ANU17335), we infer from the depleted $\delta^{13} \mathrm{C}$ values associated with these samples (Figure 4) that the molecular weight filtration did not fully exclude exogenous carbon contamination. This, we think, produced younger apparent ages, although we cannot rule out that the disagreement in bone/coffin ages may possibly be due to either reburial of older material (e.g. Coffin 11, Figure 11) or the reuse of a coffin for a later burial (e.g. Coffin 10, Figure 12). 


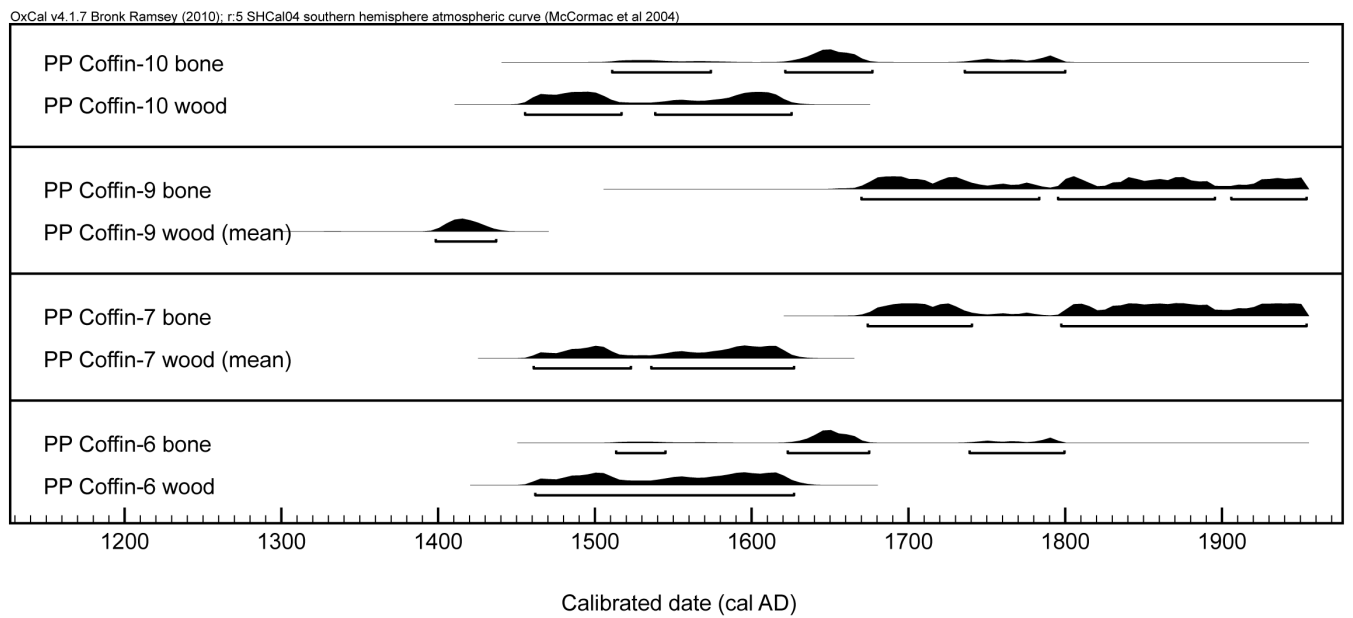

Figure 12 Multiplot of calibrated CRAs for paired bone and wood from coffins 6, 7, 9, and 10. Bone dates are significantly younger than the dates of the coffins.

\section{Damnak Samdech}

The Damnak Samdech site lies in a thickly forested situation, facing northeast at an elevation of $410 \mathrm{~m}$ asl. The site consists of 4 coffins that are 63 to $76 \mathrm{~cm}$ in length, at least 2 completely smashed Maenam Noi storage jars, a small tradeware bowl with a chakra design, and a fragment of a porcelain bowl with a blue leaf and vine design. The site has yet not had a full survey; work has been limited to an evaluation of the condition of the coffins found on the single ledge that makes up the site, examination of the small ceramics that may have been used for burial offerings, and a preliminary assessment of the poorly preserved skeletal remains (Figure 13, left).
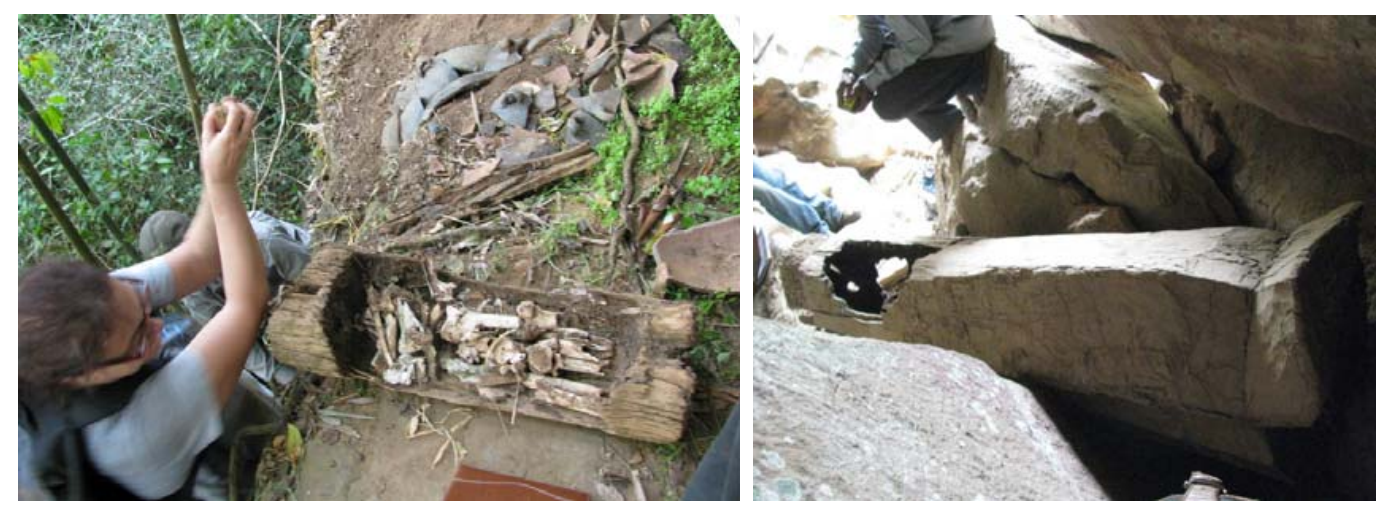

Figure 13 Coffin with human remains at Damnak Samdech (left); coffin with chevron finial carved into lid, Khnang Tathan (right).

The Damnak Samdech coffins are seriously degraded; the outer surfaces are heavily weathered and have extensive termite damage. Only 1 coffin contained human remains, which included a section of a mandible with several teeth. An M2 molar was extracted from the single mandible found in this coffin, in order to obtain a ${ }^{14} \mathrm{C}$ age from tooth enamel. The rest of the skeletal remains were left at the site until fieldwork can be scheduled to complete a full survey of the coffin burial. 
The ${ }^{14} \mathrm{C}$ result on the human tooth, of $505 \pm 35 \mathrm{BP}$ (OZO020; Table 1, Figure 2), places the burial amongst the oldest of the coffin interments. The cal AD 1400-1460 range ( $2 \sigma)$ points to the use of this site at a similar time as Phnom Pel, which is $18 \mathrm{~km}$ to the southwest of Damnak Samdech. The date also provides corroboration from a second site for the practice of coffin burial during the last century of the Angkorian period.

\section{Khnang Tathan}

The Khnang Tathan site is the farthest north and west of the overall suite of sites. It is within a rock overhang rather than a ledge, at $383 \mathrm{~m}$ asl, and faces to the west. It consists of only one 210 -cm-long coffin with a number of skeletal elements including vertebrae, finger bones, and fragments of long bone. While a fragment of skull was found, there were no teeth. The coffin is also unusual in that the lid had been given a chevron carving on both ends (Figure 13, right). This site has not had a full survey completed but we did note that there were no ceramics nor evidence such as shards to indicate ceramics had ever been in the site. A sample of wood from the outermost ring section of the whole$\log$ body was taken to obtain a ${ }^{14} \mathrm{C}$ date.

Khnang Tathan ${ }^{14} \mathrm{C}$ result was $470 \pm 30 \mathrm{BP}(\mathrm{OZO} 021$; Table 1, Figure 2). The cal AD 1430-1500 range $(2 \sigma)$ provides another example of the use of coffins in this mortuary practice at a time concurrent with the demise of Angkor as the capital of the Khmer kingdom in about AD 1432.

\section{DISCUSSION}

Twenty-five ${ }^{14} \mathrm{C}$ ages from 4 sites (excluding replicate coffin-wood ages) have been assembled for the Cardamom Mountain jar and coffin burial mortuary ritual. The appearance of such a completely distinctive burial ritual is not common in archaeological records. Such an occurrence could be indicative of a previously unrecorded people and their belief system, or an innovation by migrants, or extracultural contacts and the adoption of a new ritual by an existing culture in the highlands. Researchers such as Marie Martin, Roland Mourer and Jacques Ellul first heard of at least one of these sites in the 1960s and 1970s (Martin 1992,1997), and many more sites were discovered during a Ministry of Culture and Fine Arts survey of the region in 2000 (Somreth 2008). The current project represents the first formal effort to geo-locate the sites, and to undertake archaeological fieldwork to assess their spatial relationships, to catalog the consistency of ritual elements, and assess the time depth of the mortuary practice using direct dating methods.

The ${ }^{14} \mathrm{C}$ dating for these sites is reasonably secure, although there are anomalies. Questions discussed above about the bone results from Phnom Pel are due to the lack of IRMS measurements for $\delta^{13} \mathrm{C}$ because of extremely small sample sizes, and the poor preservation of skeletal material at that site. However, even though the suite of ${ }^{14} \mathrm{C}$ analyses have been produced at 4 different AMS facilities, and sample submission has been over the course of 8 years, the CRAs from the 4 sites all fall within a relatively tight range. The calibrated date ranges for some samples is broad due to the interception with ${ }^{14} \mathrm{C}$ plateaus and wiggles in the ${ }^{14} \mathrm{C}$ calibration curve ( $\left.\mathrm{SHCal04}\right)$. The ${ }^{14} \mathrm{C}$ ages have also been derived from 3 different materials: bone, tooth enamel, and wood.

Cluster analysis of the coffin ages at Phnom Pel suggests that the burial containers at this site may have been produced during 2 periods. Nevertheless, Bayesian modeling of the chronological sequence for Phnom Pel, including an offset of $10 \pm 2 \mathrm{yr}$, indicates a start of coffin use in cal $A D$ 1385-1445 (95\% probability; start: Phnom Pel coffins; Figure 8) and an end in cal AD 1480-1625 (95\% probability; end: Phnom Pel coffins; Figures 8, 9). The ${ }^{14} \mathrm{C}$ ages from the coffins and skeletal material are in accord with the 14th-16th centuries AD Maenam Noi storage jars (Grave and Maccheroni 2009:201; Shaw 2009:31-2) used for the bone collections at the site, although we entertain 
the idea that the coffins may be an earlier phase of this burial ritual, and that the use of imported Maenam Noi jars overlapped coffin use.

The Cardamom sites apparently cover only a short timespan, as no site has yet been dated that produced reliable ages earlier than cal AD 1395 (Table 1, Coffin 9 mean), nor later than cal AD 1650. The ${ }^{14} \mathrm{C}$ results now in hand indicate that the mortuary practice began during the late Angkorian period (15th century AD). The ritual practice, however, has no relationship with any known mortuary practices during pre-Angkorian times or with the typical Hindu/Buddhist cremation rites in the 9th to 15th centuries of the Angkorian era. Like many similar practices of exposed jar and coffin interment elsewhere in Mainland and Island Southeast Asia, the Cardamom Mountain ritual appears to be a highland culture's animist practice, although its genesis and the identity of the people creating the Cardamom practices is still a mystery.

What is especially remarkable about the Cardamom sites, and suggests much about their inter-relationship and the cultural similitude of those who created them, is the overall uniformity of the material aspects of the ritual for the dead. This uniformity includes such items as the small nautical tradeware bowls and plates that were possibly used for food offerings, the use of coffins in 3 of the 4 sites presented here, and the Maenam Noi jars used for the burials in all but the Khnang Tathan site. It is not remarkable that ceramics such as Maenam Noi, Sisatchanili, and other nautical tradeware are present in Cambodia during the period. Such tradeware was widely dispersed across sites in Mainland and Island SE Asia, as well as in Japan and the Philippines (Valdes et al. 1992). Indeed, a typical nautical trade cargo of varied ceramic goods of the period, including an abundance of Maenam Noi storage jars, was recovered in 2005 from the Koh Sdech shipwreck, off the coast of Koh Kong Province in the southwestern Cardamom Mountains. Finding these tradeware ceramics in the Cardamom sites, however, indicates that these items also penetrated into the highlands, possibly through the process of simple commerce with the nautical trade networks of the period, like those in the Gulf of Thailand along the Cambodian coast. Zhou Daguan, a Chinese emissary visiting Angkor in 1293, had commented on how mountain ethnic groups collected and sold exotic and desirable forest products such as resin, elephant tusks, and cardamom (Zhou Daguan in Harris 2007:69); these products would have been sought by supracultural traders.

As we begin to understand the time depth and the uniformity of the burial practice at numerous sites over considerable distances, and that the ritual is unrelated to lowland Khmer culture of the period, we begin to question the ethnic affinity of the people whose bones are interred in the Cardamom Mountain jar and coffin burials. The site creators may have been related to one of the existing "geocultural ensemble" (Martin 1997) of Khmer Daeum ("original" Khmer), which included the Suoy, the Samre, and the Pear/Por groups. These groups are still extant in the Cardamom Massif as well as in some Cambodian coastal provinces, but they make up a miniscule proportion of modern mountain populations. Until the 1960s, the Khmer Daeum groups spoke dialects related to Old Khmer. Pear/Por and Khmer oral traditions mention a Chong "empire" in the period before the Angkor Empire, with its capital at Sebap hill near the town of Chanthaburi in Thailand (Martin 1997:70). According to one legend, the Pear/Por of Kulen (to the north of Angkor) emigrated to the Cardamoms and found kravanh (the highest quality cardamom, Amomum kravanh), a spice that was part of divine offerings in the 11th century. The Samre, who lived in Pursat Province where the northernmost ranges of the Cardamom Mountain lie, also had legends of a Chong empire that predated the entry of Khmers into the region. Martin's conclusion was that the Chong were probably the autochthonous group occupying the Cardamom Massif foothills (Martin 1992, 1997). Nothing is known of the mortuary rituals of these ancient hill tribes, but while the modern inhabitants of the Cardamoms hold these sites to be sacred to mountain spirits (the neak ta), these people do not themselves prac- 
tice a similar mortuary ritual. Funerary rituals are not homogenous among modern Cardamom Mountain inhabitants. One of these mortuary practices is to first bury a body, collect the bones at a later time for cremation, and then place the ashes in a funerary tower (Phnom Yong Kmouch) where the soul of the deceased is thought to live. These towers are not maintained, and the nature of their construction makes them less permanent than the jar and coffin burial practice (E Zucker, personal communication, 5 November 2011).

The Cardamom Mountain jar and coffin burial sites may comprise the only remaining evidence of a highland ethnic minority practice in the Late- to Post-Angkorian period, and of a people whose lives were contemporary with, yet a world apart, from Angkor. We do not yet understand the meanings that the coffins and imported jars had in this belief system, or if the start of the practice could be due to extracultural contacts at some earlier time, but our corpus of ${ }^{14} \mathrm{C}$ dates do allow us to develop a chronology of these ancient practices. It also demonstrates the enormous potential of Cardamom Mountain jar and coffin burial sites to divulge their lost histories, and how these revelations may enhance our understanding of Khmer cultural history beyond the legacies of the great Angkor kingdom and its monumental architecture.

\section{ACKNOWLEDGMENTS}

We first would like to thank the 4 anonymous reviewers who provided the insightful comments that greatly improved the original manuscript. We also extend our thanks to Prof Gordon Cook of SUERC who provided the replicate dating of coffin wood, and Dr Quan Hua (ANSTO) for advice on the application of the Southern Hemisphere ${ }^{14} \mathrm{C}$ correction with appropriate offsets. Dr Eve Zucker provided useful information on highland funeral practices from her 2003 ethnological field notes for the Cardamoms. Dr Rodger J Sparks provided insights on dating and stable isotope issues. Mr Somreth Siphouen generously shared his Master's thesis proposal for information on the survey of the jar and coffin burial sites in 2000. We thank Geraldine Jacobson at the ANSTO Sample Preparation Laboratory and Kelly Strzepek at the ANU Sample Preparation Laboratory. We acknowledge the assistance provided since 2004 from the Cambodian Ministry of Culture and Fine Arts Department of Archaeology and Prehistory, and especially thank Their Excellencies Him Chhem, Ouk Sophon, and Hap Touch, as well as Mr Ham Kimson, Mr Heng Sophady, and Mr Voeun Vuthy. Vital helicopter and field support came from Ms Suwanna Gauntlet, CEO of WildLife Alliance (Cambodia), and Mr Prom Heong of the Chi Phat Community-Based Ecotourism program. Funding for the original 2003 expedition to the Cardamom jar and coffin sites was provided by National Geographic Television. Subsequent years of fieldwork and AMS dating were funded by the University of Sydney Research and Development Fund (2007), an Australian Research Council (ARC) Discovery Grant (DP0984968; 2008/11), the University of Otago Medical School (2010-2011), and The Ragano Family Trust (2010-2011).

\section{REFERENCES}

Bayliss A. 2009. Rolling out revolution: using radiocarbon dating in archaeology. Radiocarbon 51(1):12347.

Beavan-Athfield NR, McFadgen BG, Sparks RJ. 2001. Environmental influences on dietary carbon and ${ }^{14} \mathrm{C}$ ages in modern rats and other species. Radiocarbon 43(1):7-14.

Bellwood PJ. 1976. Archaeological research in Minahasa and the Talaud Islands, Northeastern Indonesia. Asian Perspectives 19(2):240-8.
Bellwood PJ. 2007. Prehistory of the Indo-Malaysian Archipelago. Canberra: ANU E-Press. 385 p.

Brock F, Bronk Ramsey C, Higham T. 2007. Quality assurance of ultrafiltered bone dating. Radiocarbon 49(1):187-92.

Bronk Ramsey C. 2009. Bayesian analysis of radiocarbon dates. Radiocarbon 51(1):337-60.

Brown R. 2004. The Ming Gap and shipwreck ceramics in Southeast Asia [PhD dissertation]. Department of Art History, University of California, Los Angeles. 
Buck CE, Cavanagh WG, Litton CD. 1996. Bayesian Approach to Interpreting Archaeological Data. Chichester: John Wiley \& Sons. 402 p.

Coedès G. 1968. The Indianized States of Southeast Asia. Honolulu: University of Hawaii Press.

Cort LA, Massumeh F, Gunter AC. 2000. Asian Traditions in Clay: The Hauge Gifts. Washington, DC: Freer Gallery of Art and Arthur M Sackler Gallery, 148 , no. 74

Dressler JR. 2010. Plotting history - the interdependent development of Siamese and Cambodian chronicles. In: Proceedings of the International Conference on Language, Society, and Culture in Asian Contexts. Thailand: Faculty of Humanities and Social Sciences, Mahasarakham University. p 335-47.

Fallon SJ, Fifield JK, Chappell JM. 2010. The next chapter in radiocarbon dating at the Australian National University: status report on the single stage AMS. $\mathrm{Nu}$ clear Instruments and Methods in Physics Research B 268(7-8):898-901.

Fink D, Hotchkis M, Hua Q, Jacobsen G, Smith AM, Zoppi U, Child D, Mifsud C, van der Gaast H, Williams A, Williams M. 2004. The ANTARES AMS Facility at ANSTO. Nuclear Instruments and Methods in Physics Research B 223-224:109-15.

Fox RB. 1970. The Tabon Caves. Manila: National Museum Monograph 1.

Grave P, Maccheroni M. 2009. Characterizing Asian stoneware jar production at the transition to the early Modern period, 1550-1650. In: McCarthy B, Salzman-Chase E, Cort LA, Douglas JG, Jett P, editors. Scientific Research on Historic Asian Ceramics. Proceedings of the Fourth Forbes Symposium at the Freer Gallery of Art. London: Archetype Publications. $110 \mathrm{p}$.

Hagesteijn R. 1989. Circles of Kings: Political Dynamics in Early Southeast Asia. Dordrecht: Foris Publications. $175 \mathrm{p}$.

Hagesteijn R. 1996. Lack of limits: cultural aspects of state formation in early continental Southeast Asia. In: Claessen HJM, Oosten JG, editors. Ideology and the Formation of Early States. New York: Brill. 444 p.

Harris P. 2007. Zhou Daguan: A Record of Cambodia, the Land and Its People. Chiang Mai: Silkworm Books. $150 \mathrm{p}$.

Harrisson T. 1962. Borneo death. Bijdragen tot de Taal, Lan-en Volkenkunde 118:1-41.

Harrisson T. 1974. Early 'jar burials' in Borneo and elsewhere. Asian Perspectives 17(2):141-4.

Higham C, Thosarat R. 1998. Prehistoric Thailand: From Early Settlement to Sukhothai. Bangkok: River Books. $234 \mathrm{p}$.

Higham C. 2002. Early Cultures of Mainland Southeast Asia. Bangkok: River Books. 376 p.

Hoper ST, McCormac FG, Hogg AG, Higham TFG, Head MJ. 1998. Evaluation of wood pretreatments on oak and cedar. Radiocarbon 40(1):45-50.
Horr DA. 1959. Area 19-Southeast Asia, No. 1. COWA Survey. Cambridge: Council for Old World Archaeology.

Hotchkis MAC, Fink D, Jacobsen GE, Lawson EM, Shying M, Smith AM, Tuniz C, Barbetti M, Grave P, Hua Q, Head J. 1994. ${ }^{14} \mathrm{C}$ analyses at the ANTARES AMS Centre: dating the log coffins of northwest Thailand. Nuclear Instruments and Methods in Physics Research $B$ 92(1-4):27-30.

Hua Q, Jacobsen GE, Zoppi U, Lawson EM, Williams AA, Smith AM, McGann MJ. 2001. Progress in radiocarbon target preparation at the ANTARES AMS Centre. Radiocarbon 43(2A):275-82.

Hua Q, Barbetti M, Zoppi U, Fink D, Watanasak M, Jacobsen GE. 2004. Radiocarbon in tropical tree rings during the Little Ice Age. Nuclear Instruments and Methods in Physics Research B 223-224:489-94.

Hurst S, Carter BJ, Beavan-Athfield N. 2010. Investigation of a 10,214 BP Late Paleoindian bison kill at the Howard Gully Site in southwestern Oklahoma. Plains Archaeologist 55(213):25-37.

Kurjack EB, Sheldon CT. 1970. The archaeology of Seminoho Cave in Lebak, Cotobato. Silliman Journal 17:5-18.

Kurjack EB, Sheldon CT. 1971. The urn burial caves of Southern Cotobato, Mindanao, Philippines. Silliman Journal 18:127-53.

Martin MA. 1992. Histoire du peuplement du massif des Cardamomes sous la monarchie khmère. In: Condominas G, editor. Disciplines Croisées: Hommage a Bernard Philippe Groslier. Paris: École des Hautes Études en Sciences Sociales. p 219-54.

Martin MA. 1997. Les Khmers Daeum "Khmers de l'origine." Paris: Pressés de l'École Française d'Extrême-Orient, Monographies no. 183.

Metcalf P, Huntington R. 1991. Celebrations of Death: The Anthropology of Mortuary Ritual. 2nd edition. Cambridge: Cambridge University Press. 258 p.

McCormac FG, Hogg AG, Blackwell PG, Buck CE, Higham TFG, Reimer PJ. 2004. SHCal04 Southern Hemisphere calibration, 0-11.0 cal kyr BP. Radiocarbon 46(3): 1087-92.

McFadgen BG, Knox FB, Cole TRL. 1994. Radiocarbon calibration curve variations and their implications for the interpretation and timing of New Zealand prehistory. Radiocarbon 36(2):221-36.

Mook WG. 1986. Business meeting: recommendations/ Resolutions adopted by the Twelfth International Radiocarbon Conference. Radiocarbon 28(2A): 799.

Mouret C. 2000. Grottes et falaises se'pulcrales de Luzon et Sulawesi [Burial caves and cliffs of Luzon and Sulawesi]. In: Actes de la 10e 'me Rencontre d'Octobre. Paris: Speleo-Club de Paris.

Mouret C. 2004. Burials in caves. In: Gunn J, editor. Encyclopedia of Caves and Karst Science. New York: Taylor and Francis. 960 p.

O'Reilly D. 2007. Early Civilizations of Southeast Asia. 
Lanham: AltaMira Press. 238 p.

Pelliot P. 1903. Le Fou-nan. Bulletin de l'Ecole Française d'Extrême-Orient 3(2):248-303.

Peterson BJ, Fry B. 1987. Stable isotopes in ecosystem studies. Annual Review of Ecological Systems 18: 293-320.

Pitiphat S. 1992. Ceramics from the Thai-Burma Border. Bangkok: Thai Khadi Research Institute, Thammasat University. 190 p.

Santos GM, Southon JR, Druffel-Rodriguez KC, Griffin S, Mazon M. 2004. Magnesium perchlorate as an alternative water trap in AMS graphite sample preparation: a report on sample preparation at the KCCAMS Facility at the University of California, Irvine. Radiocarbon 46(1): 165-73.

Sayavongkhamdy T, Bellwood P. 2000. Recent archaeological research in Laos. The Melaka Papers, Volume 3. Indo-Pacific Prehistory Association Bulletin 19: 101-10.

Shaw JC.1985. Tak hilltop burial sites. Arts of Asia JulyAug:95-102.

Shaw JC. 1986. The kilns of Lan Na and the Tak hilltop burial sites. The Siam Society Newsletter 2(4):1-13.

Shaw JC. 2009. Thai Ceramics. Bangkok: Craftsman Press. 119 p.

Slota PJ, Jull AJT, Linick TW, Toolin LJ. 1987. Preparation of small samples for ${ }^{14} \mathrm{C}$ accelerator targets by catalytic reduction of CO. Radiocarbon 29(2):303-6.

Somreth S. 2008. Les Urns et les Rites Funerraires des montagne Cardamomes au Cambodge [unpublished proposal for a Master's thesis]. Toronto: University of Toronto.

Sørensen P. 1973. Prehistoric iron implements from Thailand. Asian Perspectives 17(2):134-73.

Stark MT. 2001. Some preliminary results of the 19992000 archaeological field investigations at Angkor Borei, Takeo Province. Udaya 2:19-31.

Stuiver M, Kra RS. 1986. Editorial comment. Radiocarbon 28(2B):ii.

Stuiver M, Polach HA. 1977. Discussion: reporting of ${ }^{14} \mathrm{C}$ data. Radiocarbon 19(3):355-63.

Stuiver M, Reimer PJ. 1986. A computer program for radiocarbon age calibration. Radiocarbon 28(2B): 1022-30.

Stuiver M, Reimer PJ. 1993. Extended ${ }^{14} \mathrm{C}$ data base and revised CALIB $3.0{ }^{14} \mathrm{C}$ calibration program. Radiocarbon 35(1):215-30.

Szabo K, Piper PJ, Barker G. 2008. Sailing between worlds: the symbolism of death in northwest Borneo.
In: Clark G, Leach F, O'Connor S, editors. Islands of Inquiry Colonisation, Seafaring and the Archaeology of Maritime Landscapes. Terra Australis 29. Canberra: ANU E-Press. p 149-70.

Tsuda T. 1999. Myanmaa, Mandaree shhen no dokizukuri mura to sumkingu piipu [Earthenware-making villages and smoking pipes around Mandalay in Myanmar]. Tnan Ajia kokogaku [Journal of Southeast Asian Archaeology] (Journal of the Japan Society of Southeast Asian Archaeology) 19:115-360. In Japanese with English summary.

Valdes CO, Nguyen-Long K, Barbosa AC. 1992. A Thousand Years of Stoneware in the Philippines. Makati, Metro Manila: National Museum and the Oriental Ceramic Society of the Philippines.

Vandeputte K, Moens L, Dams R. 1996. Improved sealed-tube combustion of organic samples to $\mathrm{CO}_{2}$ for stable isotope analysis, radiocarbon dating and percent carbon determinations. Analytical Letters. 29(15):2761-73.

Wannasri S, Pumijumnong N, Shoocongdej R. 2007. Teak log coffin head styles in northern Thailand: time sequencing with dendrochronology. ScienceAsia 33(1):47-56.

Ward GK, Wilson SR. 1978. Procedures for comparing and combining radiocarbon age determinations: a critique. Archaeometry 20(1):19-31.

Wilson SR, Ward GK. 1981. Evaluation and clustering of radiocarbon age determinations: procedures and paradigms. Archaeometry 23(1):19-39.

Wolters OW. 1974. North-western Cambodia in the seventh century. Bulletin of the School of Oriental and African Studies, University of London 37(2):355-84.

Wolters OW. 1979. Khmer 'Hinduism' in the seventh century in Early South East Asia. In: Smith RB, Watson W, editors. Essays in Archaeology, History and Historical Geography. New York: Oxford University Press. p 427-56.

Woodman N, Beavan-Athfield N. 2009. Post-Clovis survival of American mastodon in the southern Great Lakes region of North America. Quaternary Research 72(3):359-63.

Xu S, Anderson R, Bryant C, Cook GT, Dougans A, Freeman S, Naysmith P, Schnabel C, Scott EM. 2004. Capabilities of the new SUERC 5MV AMS facility for ${ }^{14} \mathrm{C}$ dating. Radiocarbon 46(1):59-64.

Zazzo A, Saliège J-F. 2011. Radiocarbon dating of biological apatites: a review. Palaeogeography, Palaeoclimatology, Palaeoecology 310(1-2):52-61. 